\title{
Rapid intercontinental air pollution transport associated with a meteorological bomb
}

\author{
A. Stohl ${ }^{1}$, H. Huntrieser ${ }^{2}$, A. Richter ${ }^{3}$, S. Beirle ${ }^{4}$, O. R. Cooper ${ }^{5}$, S. Eckhardt ${ }^{1}$, C. Forster ${ }^{1}$, P. James ${ }^{1}$, N. Spichtinger ${ }^{1}$, \\ M. Wenig ${ }^{6}$, T. Wagner ${ }^{4}$, J. P. Burrows ${ }^{3}$, and U. Platt ${ }^{4}$ \\ ${ }^{1}$ Department of Ecology, Technical University of Munich, Germany \\ ${ }^{2}$ Institute for Atmospheric Physics, DLR, Oberpfaffenhofen, Germany \\ ${ }^{3}$ Institute of Environmental Physics, University of Bremen, Germany \\ ${ }^{4}$ Institute of Environmental Physics, Heidelberg University, Germany \\ ${ }^{5}$ Cooperative Institute for Research in Environmental Sciences (CIRES), University of Colorado/NOAA Aeronomy \\ Laboratory, Boulder, USA \\ ${ }^{6}$ NASA Goddard Space Flight Center, Code 916, Greenbelt, MD, USA
}

Received: 19 February 2003 - Published in Atmos. Chem. Phys. Discuss.: 16 April 2003

Revised: 20 June 2003 - Accepted: 8 July 2003 - Published: 9 July 2003

\begin{abstract}
Intercontinental transport (ICT) of trace substances normally occurs on timescales ranging from a few days to several weeks. In this paper an extraordinary episode in November 2001 is presented, where pollution transport across the North Atlantic took only about one day. The transport mechanism, termed here an intercontinental pollution express highway because of the high wind speeds, was exceptional, as it involved an explosively generated cyclone, a so-called meteorological "bomb". To the authors' knowledge, this is the first study describing pollution transport in a bomb. The discovery of this event was based on tracer transport model calculations and satellite measurements of $\mathrm{NO}_{2}$, a species with a relatively short lifetime in the atmosphere, which could be transported that far only because of the high wind speeds produced by the bomb. A 15-year transport climatology shows that intercontinental express highways are about four times more frequent in winter than in summer, in agreement with bomb climatologies. The climatology furthermore suggests that intercontinental express highways may be important for the budget of short-lived substances in the remote troposphere. For instance, for a substance with a lifetime of 1 day, express highways may be responsible for about two thirds of the total ICT. We roughly estimate that express highways connecting North America with Europe enhance the average $\mathrm{NO}_{\mathrm{x}}$ mixing ratios over Europe, due to North American emissions, by about $2-3$ pptv in winter.
\end{abstract}

Correspondence to: A. Stohl

(stohl@forst.tu-muenchen.de)

\section{Introduction}

\subsection{Meteorological bombs}

Cyclones are a key element of the atmospheric circulation in the midlatitudes (Carlson, 1998). Cyclogenesis, for which a first conceptual model was presented by the Bergen school (Bjerknes, 1910), occurs most frequently at the polar front. The various ascending and descending airstreams typically associated with these cyclones carry a range of different chemical signatures (Cooper et al., 2002). The so-called warm conveyor belt (WCB) - a strongly ascending airstream ahead of a cyclone's cold front (Browning et al., 1973) - is an important mechanism to lift air pollutants emitted at the surface into the upper troposphere, where the faster winds facilitate their intercontinental transport (ICT) (Stohl and Trickl, 1999). Thus, cyclones are important not only for the dynamics of the atmosphere, but also for its chemistry.

Some cyclones develop so explosively that they became known as meteorological "bombs" (Sanders and Gyakum, 1980). The characteristic features of a bomb are a rapid central pressure reduction and an attendant increase in intensity. Since the pioneering study of Sanders and Gyakum (1980), henceforth referred to as SG1980, explosive cyclogenesis is defined by a fall of more than $1 \mathrm{hPa} / \mathrm{hour} \times(\sin \phi / \sin 60)$, where $\phi$ is latitude, of a cyclone's minimum sea-level pressure, over a period of at least 24 hours.

Explosive cyclogenesis requires extremely high levels of baroclinicity near the cyclone track (Ulbrich et al., 2001) and/or extremely strong release of latent heat (Zhu and Newell 2000; Wernli et al. 2002). Cold air encircling the bomb's center at low altitudes pushes the warmer air up in a spiral-like way (Lemaitre et al., 1999), which sometimes 
leads to eye-like structures known from tropical cyclones (SG1980). During their life-cycles, bombs can attain extremely low core sea-level pressures (SG1980), and, thus, horizontal pressure gradients - and surface winds - can be extreme. Their scales range from rather small-scale vortices that do not change the large-scale circulation significantly (Ulbrich et al., 2001) to larger-than-normal cyclones (Lim and Simmonds, 2002).

Bombs are a great danger, especially for shipping. For instance, the Sydney-Hobart yacht race cyclone in December 1998 resulted in the death of six race participants (Buckley and Leslie, 2000). Like tropical cyclones, bombs weaken after landfall, but to a much lesser extent. Surface wind gusts above $50 \mathrm{~m} \mathrm{~s}^{-1}$ have been reported over land. Examples of destructive bombs over Europe are the great storm of October 1987 over southern England (Burt and Mansfield, 1988) and the Christmas storms of 1999, that claimed 130 lives and caused 13 billion Euros worth of total economic losses in central Europe (Ulbrich et al., 2001). The danger of bombs also comes from their explosive development and their rapid motion, both of which are often not well predicted by weather forecast models (Sanders et al., 2000).

Explosive cyclogenesis is a phenomenon occurring most often in winter and almost exclusively over the oceans. About 50 bombs per year are found on the Northern Hemisphere (Lim and Simmonds, 2002), most of them over the warm surface waters downstream of Asia and North America (SG1980), regions with frequent and intense WCBs and corresponding strong latent heat release (Stohl, 2001). There is a statistically significant upward trend of global bomb occurrence during the last two decades, which may be related to global warming (Lim and Simmonds, 2002).

\subsection{Long-range $\mathrm{NO}_{\mathrm{x}}$ transport}

ICT of trace substances is a topic that currently receives much attention, due to its implications both for air quality and climate. ICT is reasonably well documented (e.g., Jaffe et al. 1999; Stohl and Trickl 1999; Forster et al. 2001) for moderately long-lived species (e.g., carbon monoxide, ozone, aerosols), but so far has been considered insignificant for species with lifetimes of hours to a few days. Among these shorter-lived species, nitrogen oxides $\left(\mathrm{NO}_{\mathrm{x}}\right)$ - which have a lifetime on the order of hours in the atmospheric boundary layer (ABL) and a few days in the upper troposphere (Jaeglé et al., 1998) - are of particular interest, because they are critical for photochemical formation of ozone $\left(\mathrm{O}_{3}\right)$ in the troposphere (Lin et al., 1988). Below a certain concentration of nitric oxide ( $\mathrm{NO}), \mathrm{O}_{3}$ is destroyed, whereas above it is formed. Values of this so-called compensation point vary, but are on the order of 10 to $30 \mathrm{ppt}$, with lower values in the upper troposphere (e.g., Reeves et al., 2002). Aircraft measurements show that $\mathrm{NO}_{\mathrm{x}}$ levels in the remote free troposphere, particularly in the upper troposphere, of- ten exceed this threshold (Bradshaw et al., 2000), leading to substantial in-situ $\mathrm{O}_{3}$ formation.

Strong filamentation of pollution plumes normally takes place during ICT. The large surface/volume ratio of filaments increases the probability of mixing of the polluted air with the surrounding cleaner airmasses. If this process is fast enough for $\mathrm{NO}_{\mathrm{x}}$ to be still contained in the plume, the efficiency of $\mathrm{O}_{3}$ production (i.e., the number of molecules of $\mathrm{O}_{3}$ produced per molecule of $\mathrm{NO}_{\mathrm{x}}$ available) increases (Lin et al., 1988), because of a higher hydrocarbon/ $/ \mathrm{NO}_{\mathrm{x}}$ ratio in the mixed airmass (note that sufficiently high levels of hydrocarbons, e.g., methane, are contained in "background" air).

ICT of $\mathrm{NO}_{\mathrm{x}}$ also can occur in the form of reservoir species $\left(\mathrm{NO}_{\mathrm{y}}\right.$, e.g., peroxy acetyl nitrate), which are products from $\mathrm{NO}_{\mathrm{x}}$ oxidation, from which $\mathrm{NO}_{\mathrm{x}}$ can be re-cycled at a later time. This is thought to be important for photochemical $\mathrm{O}_{3}$ formation in the background free troposphere (e.g., Wild et al., 1996). However, even export of $\mathrm{NO}_{\mathrm{y}}$ from the $\mathrm{ABL}$ to the free troposphere is very inefficient (Prados et al., 1999). Model studies (Liang et al., 1998) suggest that only 15-25\% of the $\mathrm{NO}_{\mathrm{x}}$ emitted at the surface reaches the free troposphere, and observations show that only about $5-10 \%$ of the originally emitted nitrogen remains in the atmosphere after a few days (Stohl et al., 2002b). Models and measurements agree that only a small fraction of the exported nitrogen is in the form of $\mathrm{NO}_{\mathrm{x}}$.

Given the inefficient vertical transport of boundary-layer $\mathrm{NO}_{\mathrm{x}}$, both aircraft (Ziereis et al., 2000) and, especially, lightning (Huntrieser et al. 2002; Jeker et al. 2000) emissions of $\mathrm{NO}_{\mathrm{x}}$ are thought to play important roles in the free troposphere. Indeed, large-scale $\mathrm{NO}_{\mathrm{x}}$ plumes have been found in the upper troposphere over North America (Brunner et al., 1998), that possibly were produced by lightning.

Satellite data from the Global Ozone Monitoring Experiment (GOME) (Burrows et al., 1999) confirm that, on a climatological basis, $\mathrm{NO}_{\mathrm{x}}$ is highly concentrated in its major source regions, implying an average $\mathrm{NO}_{\mathrm{x}}$ lifetime in the atmosphere of about 1 day (Leue et al., 2001). Nevertheless, two episodes where GOME showed ICT of $\mathrm{NO}_{\mathrm{x}}$ were recently described. One was due to boreal forest fire emissions, where $\mathrm{NO}_{\mathrm{x}}$ was injected directly into the free troposphere and subsequently transported rapidly from Canada to the west coast of Europe (Spichtinger et al., 2001). In the second case, $\mathrm{NO}_{\mathrm{x}}$ from power plants in the South African Highveld, again injecting $\mathrm{NO}_{\mathrm{x}}$ into the free troposphere, were transported to the Indian Ocean and, presumably, to Australia (Wenig et al., 2002). Furthermore, lightning $\mathrm{NO}_{\mathrm{x}}$ emissions also played a role in this case.

In this paper, a third case of $\mathrm{NO}_{\mathrm{x}}$ ICT is reported, that is, so far, the clearest example of its kind and does neither involve direct deposition of emissions into the free troposphere, nor significant lightning emissions. Instead, average advection speeds above $40 \mathrm{~m} \mathrm{~s}^{-1}$ south of a bomb center allowed ICT of $\mathrm{NO}_{\mathrm{x}}$ from anthropogenic surface sources to occur within less than two days. Furthermore, in order to 
judge the relevance of events similar to the one observed, a 15-year climatology of fast ICT of anthropogenic emission tracers is presented.

\section{Methods}

In November 2001, the first aircraft campaign of the CONTRACE (Convective Transport of Trace Gases into the Upper Troposphere over Europe: Budget and Impact on Chemistry) project took place in Germany. One aim of this project was to make measurements in the outflow of polluted North Atlantic WCBs. Due to successful tracer model forecasts (Lawrence et al. 2003; Stohl et al. 2003), it was indeed possible to probe pollution plumes from North America on three occasions, allowing, for the first time, a detailed chemical characterisation of such plumes over Europe (Huntrieser et al., 2003). After the campaign, tropospheric $\mathrm{NO}_{2}$ columns retrieved from spectral data of the GOME satellite sensor (Burrows et al., 1999) were used as supplementary information on the transport of pollution plumes across the Atlantic. Unfortunately, few GOME data were available during the aircraft campaign, because the instrument was turned off for protection during the Leonides meteor shower. However, immediately before the first measurement flight, an episode of $\mathrm{NO}_{2}$ transport from North America to Europe was seen in the GOME data, that agrees remarkably well with tracer model calculations, and which is presented in this paper.

\subsection{Tropospheric $\mathrm{NO}_{2}$ columns from GOME}

The Global Ozone Monitoring Experiment (GOME) (Burrows et al., 1999) is a UV / visible spectrometer operating on the ERS-2 satellite since July 1995. GOME observes the solar radiance scattered in the atmosphere and reflected from the surface in near nadir viewing geometry. Once per day, it also takes an irradiance measurement of the sun providing an absorption free background spectrum. The instrument covers the spectral range from 240 to $790 \mathrm{~nm}$ in 4096 spectral channels at a resolution of $0.2-0.4 \mathrm{~nm}$. The ERS-2 satellite is in a sun-synchronous near polar orbit with an equator crossingtime of 10:30. As a result, measurements at a given latitude are always at the same local time. The GOME instrument scans across the track from east to west taking three measurements of $320 \times 40 \mathrm{~km}^{2}$ through its swath of $960 \mathrm{~km}$. With this scan pattern, global coverage is achieved in three days at the equator and in one day at $65^{\circ}$.

From the nadir measurements and the irradiance background, integrated columns can be retrieved for a number of atmospheric trace species including $\mathrm{O}_{3}, \mathrm{NO}_{2}, \mathrm{BrO}$, $\mathrm{SO}_{2}, \mathrm{HCHO}$, and $\mathrm{H}_{2} \mathrm{O}$ (Burrows et al., 1999) using the well known Differential Optical Absorption Spectroscopy (DOAS) method (Platt, 1994). Briefly, absorbers are identified by the "fingerprint" of the wavelength dependence of their absorption structures, and the total amount of the ab- sorber along the line of sight is determined using LambertBeer's law. In a second step, this column is converted to a vertical column using airmass factors (Solomon et al., 1987) derived with a radiative transport model (Rozanov et al., 1997). Since, under clear sky conditions, a fraction of the radiation received by GOME (in particular in the visible part of the spectrum) is sunlight reflected by the surface, which travelled through the entire atmosphere, GOME measurements are sensitive to both stratospheric and tropospheric absorptions. If only the tropospheric column is of interest, the stratospheric contribution to the signal has to be corrected for, which in the case of $\mathrm{NO}_{2}$ is usually done by subtracting measurements taken on the same day at the same latitude over a clean region (Leue et al. 2001; Richter and Burrows 2002; Martin et al. 2002). This approach is based on the assumptions that a) stratospheric $\mathrm{NO}_{2}$ does not depend on longitude, and that $b$ ) the reference region has a negligible tropospheric $\mathrm{NO}_{2}$ burden. Tropospheric $\mathrm{NO}_{2}$ columns from GOME have been validated against independent measurements (Heland et al., 2002), and have been extensively compared to model results (Velders et al. 2001; Lauer et al. 2002; Martin et al. 2002).

The accuracy of tropospheric $\mathrm{NO}_{2}$ columns from GOME is mainly limited by problems associated with cloud contamination, errors introduced by the correction of the stratospheric contribution, and uncertainties in the airmass factor (Richter and Burrows, 2002). In the case study discussed here, most of the relevant scenes were cloud free (see Fig. 8), simplifying the data analysis. However, the shape of the vertical distribution of $\mathrm{NO}_{2}$ has to be taken into account for the airmass factor calculation. In the standard analysis it is assumed that the bulk of the $\mathrm{NO}_{2}$ is situated in the ABL. In the present case, however, $\mathrm{NO}_{2}$ was transported to the free troposphere, where the retrieval is more sensitive to $\mathrm{NO}_{2}$. Therefore, the standard airmass factors were used only for the source regions over the continents, whereas over the ocean it was assumed that the bulk of the $\mathrm{NO}_{2}$ was situated between 3 and $5 \mathrm{~km}$, as indicated by the transport model results presented in section 3. By this approach the $\mathrm{NO}_{2}$ vertical columns were reduced by roughly a factor of 2 over the ocean compared to the standard scientific tropospheric $\mathrm{NO}_{2} \mathrm{GOME}$ product, upon which the initial discovery of this event was based. The discovery, thus, did benefit from an overestimate of the $\mathrm{NO}_{2}$ vertical columns over the ocean in the standard product, which overemphasized the ICT. However, as the overall patterns were quite similar in both analyses, only the results obtained with the modified, more realistic, airmass factors yielding reduced $\mathrm{NO}_{2}$ columns are presented here.

Since no correction is applied for thin clouds that may have been present in the GOME pixels, the amount of $\mathrm{NO}_{2}$ is probably underestimated, as detailed in Velders et al. (2001) and Richter and Burrows (2002). Even a cloud fraction of $10 \%$ can lead to an underestimation of up to $100 \%$ in the GOME measurements if the cloud is above the $\mathrm{NO}_{2}$ layer, or an overestimation of $50 \%$ if it is below the layer. Therefore, 
GOME pixels with large cloud fractions (>50\%) were excluded from the analysis.

When comparing GOME measurements and model results, it is also important to keep in mind that GOME can only observe $\mathrm{NO}_{2}$, not $\mathrm{NO}_{\mathrm{x}}$. Depending on altitude, temperature, albedo and cloud coverage, the $\mathrm{NO}_{2} / \mathrm{NO}_{\mathrm{x}}$ ratio varies significantly in the troposphere, with most of the $\mathrm{NO}_{\mathrm{x}}$ being in the form of $\mathrm{NO}_{2}$ close to the surface and the significance of $\mathrm{NO}$ increasing with altitude. Therefore, for a given $\mathrm{NO}_{\mathrm{x}}$ vertical column, the $\mathrm{NO}_{2}$ column is smaller when the $\mathrm{NO}_{\mathrm{x}}$ is located at higher altitudes. For the high solar zenith angles encountered during this study and at temperatures typical for the mid-troposphere, both $\mathrm{NO}$ and $\mathrm{NO}_{2}$ contribute approximately $50 \%$ of the $\mathrm{NO}_{\mathrm{x}}$.

\subsection{Model simulations}

To simulate the transport, the Lagrangian particle dispersion model FLEXPART (version 4.4) (Stohl et al. 1998; Stohl and Thomson 1999; http://www.forst.tu-muenchen.de/EXT/ LST/METEO/stohl/) was used. FLEXPART was validated with data from three large-scale tracer experiments in North America and Europe (Stohl et al., 1998), and it was used previously for case studies (Stohl and Trickl 1999; Forster et al. 2001; Spichtinger et al. 2001) and a 1-year "climatology" (Stohl et al., 2002a) of ICT.

For this study, FLEXPART was used with global data from the European Centre for Medium-Range Weather Forecasts (ECMWF, 1995) with a horizontal resolution of $1^{\circ}, 60$ vertical levels and a time resolution of $3 \mathrm{~h}$ (analyses at $0,6,12$, 18 UTC; 3-hour forecasts at 3, 9, 15, 21 UTC). Data with $0.5^{\circ}$ resolution covering the domain $120^{\circ} \mathrm{W}$ to $30^{\circ} \mathrm{E}$ and $18^{\circ} \mathrm{N}$ to $66^{\circ} \mathrm{N}$ were nested into the global data in order to achieve higher spatial resolution over the region of main interest, i.e., North America, the North Atlantic, and Europe.

FLEXPART treats advection and turbulent diffusion by calculating the trajectories of a multitude of particles. Stochastic fluctuations, obtained by solving Langevin equations (Stohl and Thomson, 1999), are superimposed on the grid-scale winds to represent transport by turbulent eddies, which are not resolved in the ECMWF data. The ECMWF data also do not resolve individual deep convective cells, although they reproduce the large-scale effects of convection (e.g., the strong ascent within WCBs). To account for sub-gridscale convective transport, FLEXPART was recently equipped with the convection scheme developed by Emanuel and Živković-Rothman (1999), as described in Seibert et al. (2001).

With FLEXPART the transport of a passive tracer was calculated, representing $\mathrm{NO}_{\mathrm{x}}$ emissions from North America, taken from the EDGAR version 3.2 inventory (Olivier and Berdowski, 2001) (base year 1995, $1^{\circ}$ resolution). The simulation started on 28 October and ended on 28 November 2001. During this period, a total of 25 million particles were released between the surface and $150 \mathrm{~m}$ above the ground

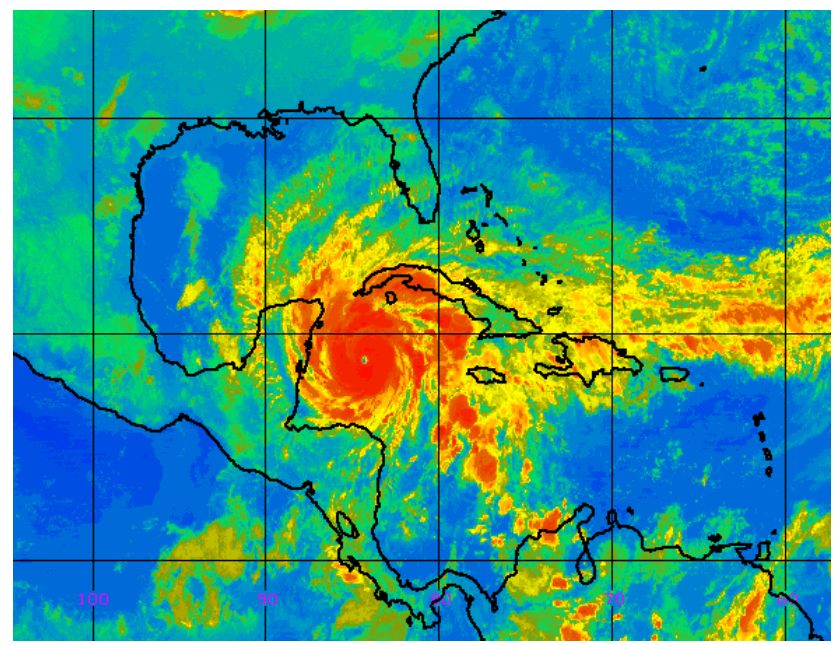

Fig. 1. GOES-East infrared satellite image of the hurricane on 3 November at 6 UTC.

at a constant rate, with the number of particles released in a particular grid cell being proportional to the emissions in that cell. An exponential decay with a time constant of two days was assumed for the $\mathrm{NO}_{\mathrm{x}}$ tracer. This is longer than the typical $\mathrm{NO}_{\mathrm{x}}$ lifetime in the $\mathrm{ABL}$, but of the right order of magnitude for $\mathrm{NO}_{\mathrm{x}}$ transport in the free troposphere. The episode of interest started on 8 November 2001, allowing a sufficiently long model spin-up of 11 days. The simulations were described in more detail by Stohl et al. (2003). Note that, because FLEXPART does not explicitly simulate chemical processes, quantification of the $\mathrm{NO}_{\mathrm{x}}$ transported is difficult and must be constrained with the GOME measurements.

\section{A case study}

\subsection{Meteorological overview}

The "express highway" in which pollution was carried rapidly from North America to Europe was created in a series of dynamical developments, which are described in this section. The most important ingredient to this episode was a bomb, which "exploded" on 7 November. This bomb itself had three precursor systems: First, a tropical depression started to develop in the Caribbean on 29 October and intensified to a category four hurricane until 4 November. In a GOES-East infrared satellite image on 3 November at 6 UTC, an eye can be seen clearly in the center of the hurricane (Fig. 1). This hurricane occurred unusually late in the season, but nevertheless was one of the strongest of the year. When it made landfall in Cuba on 4 November, wind speeds of up to $65 \mathrm{~m} \mathrm{~s}^{-1}$ caused massive destruction.

On 6 November at 0 UTC, the hurricane can still be seen as a minimum in the sea-level pressure, a map of which is shown in Fig. 2a, where the hurricane's position is marked 
a) 6 November 0 UTC

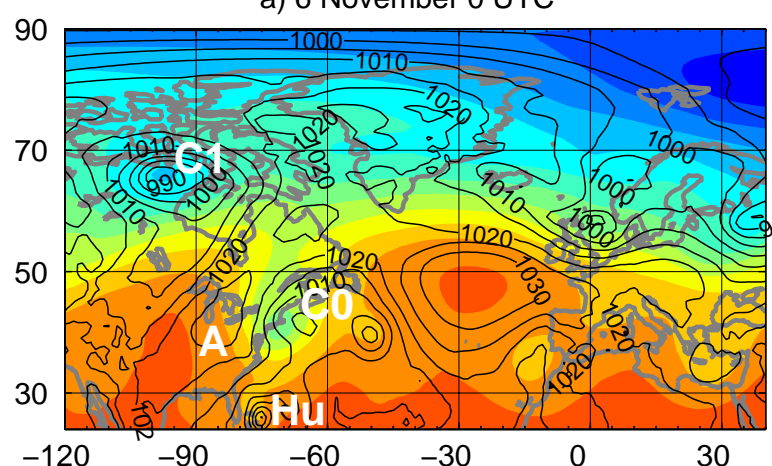

b) 6 November 18 UTC

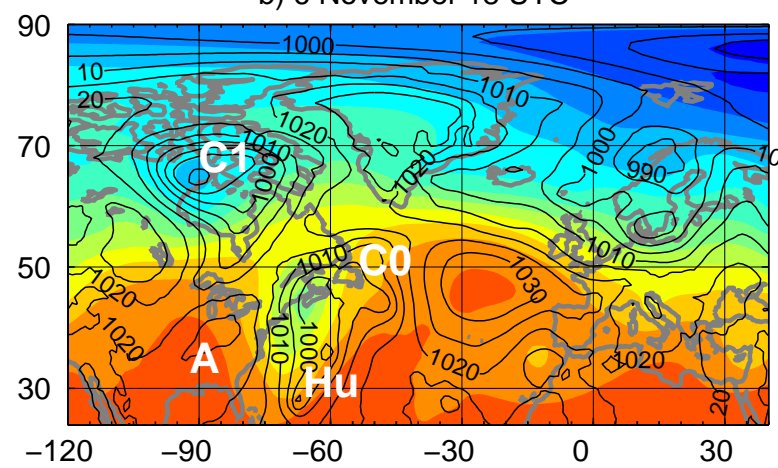

c) 8 November 0 UTC

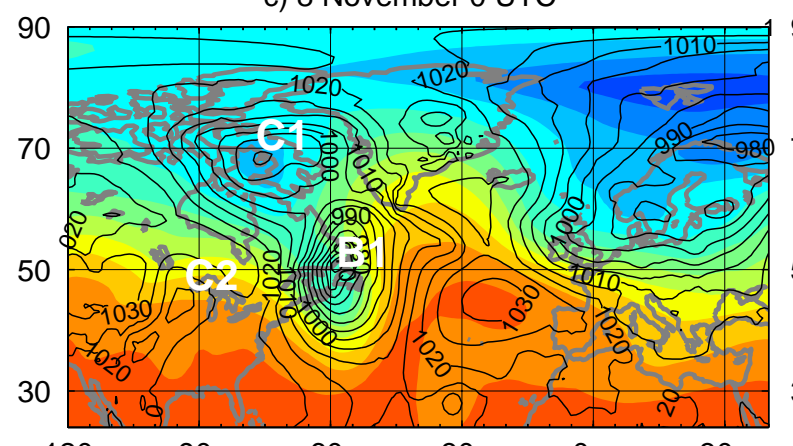

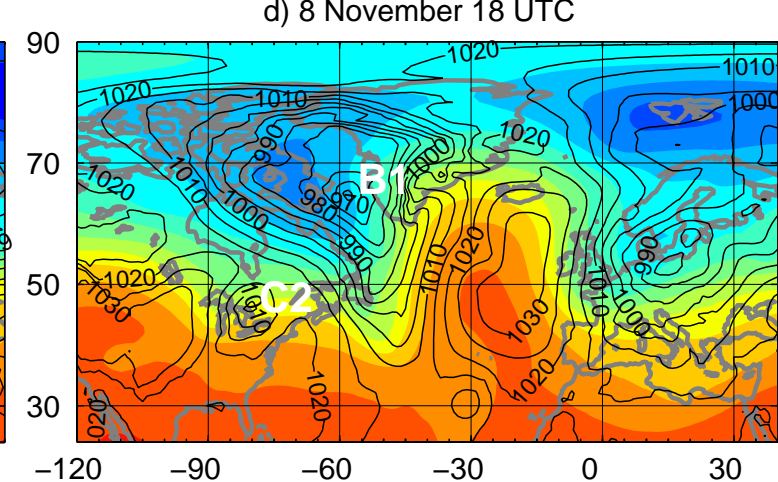

e) 9 November 18 UTC

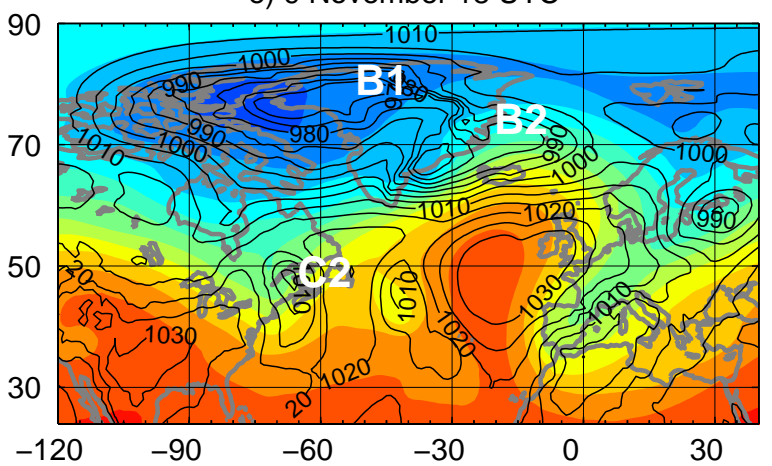

f) 10 November 12 UTC

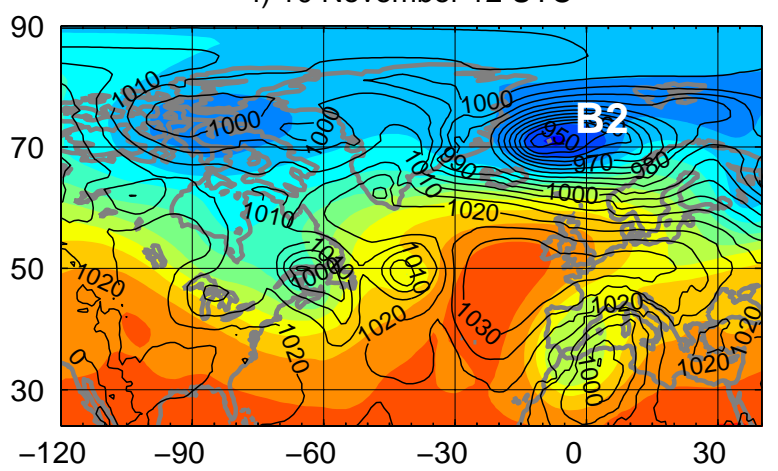

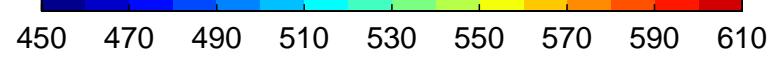

Geopotential at $500 \mathrm{hPa}$ [gpdm]

Fig. 2. Maps $\left(120^{\circ} \mathrm{W}-40^{\circ} \mathrm{E}, 25^{\circ} \mathrm{N}-90^{\circ} \mathrm{N}\right)$ of the geopotential height at $500 \mathrm{hPa}$ (color shading) and sea-level pressure (black contour lines drawn every $5 \mathrm{hPa}$ ) on 6 November 18 UTC (a), 8 November 0 UTC (b), 8 November 18 UTC (c), and 10 November 12 UTC (d), based on ECMWF analyses with a resolution of $1^{\circ}$. Continental outlines are shown as thick grey lines, and synoptic systems are labeled, as described in the text, with bold white letters northeast of their center.

with "Hu". Subsequently, the hurricane weakened, but continued heading north, carrying warm and moist tropical air with it. On 6 November at 18 UTC (Fig. 2b) it merged with the second bomb precursor, a cut-off low at $500 \mathrm{hPa}$ (labeled "CO") that had been almost stationary over the eastern seaboard of Canada since 5 November (see Fig. 2a). Cutoff low "C0" blocked continental outflow from the northern parts of the U.S. and Canada from 5 to 8 November.
The third precursor was an extratropical moving cyclone ("C1") that formed northwest of the Hudson Bay on 5 November. On 6 November at 0 UTC, "C1" was located northwest of the Hudson Bay (Fig. 2a), but reached it 18 hours later (Fig. 2b). "C1" connected to the cut-off cyclone "C0" on 7 November, and finally merged with it on 8 November (Fig. 2c-d). The mergers of both the hurricane "Hu" approaching from the south and the mobile cyclone 


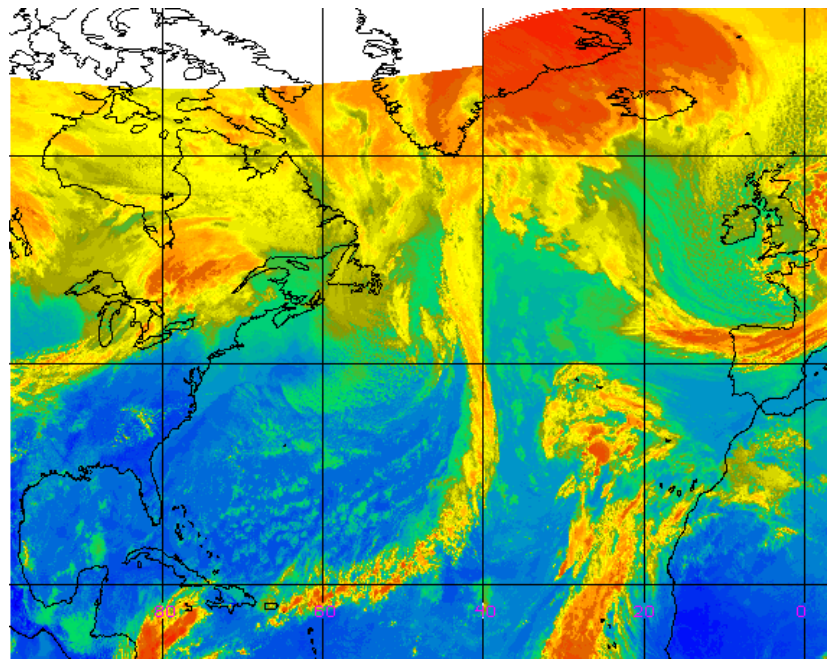

Fig. 3. Combined GOES-East and METEOSAT infrared satellite image on 8 November at 18 UTC. White areas in the northern part of the figure are regions without data.

"C1" approaching from the northwest with the cut-off cyclone "CO" in the middle, created an environment for explosive development, generating bomb "B1" on 8 November at 0 UTC (Fig. 2c).

On 8 November at 18 UTC, "B1" was centered west of Greenland (Fig. 2d). A combined GOES-East and METEOSAT infrared satellite image for 8 November at 18 UTC (Fig. 3) documents the result of this explosive cyclogenesis. It shows a truly giant bomb whose cold frontal cloud band extended from Greenland all the way into the Caribbean, and whose cloud head stretched from northern Greenland to Iceland. The total dimension of the cloud system was greater than $7000 \mathrm{~km}$.

One day later (Fig. 2e), the bomb split into two ("B1" and "B2") over Greenland. While the northern center "B1" weakened, the southern center "B2" intensified, because of cyclogenesis leewards of Greenland. On 10 November at 12 UTC (Fig. 2f), "B2" was centered northeast of Iceland and had deepened to its minimum central sea-level pressure of $948 \mathrm{hPa} .18$ hours later, on 11 November at 6 UTC (not shown), "B2" travelled into Scandinavia and subsequently into Siberia, where its core pressure finally started to increase. Due to the remoteness of northern Scandinavia, the severe weather did not cause major damage, but heavy snowfalls in the mountains and a wind speed of $43 \mathrm{~m} \mathrm{~s}^{-1}$ were reported in Lapland on 10 November. It is furthermore to be noted that the bomb likely had triggered downstream Rossby wave breaking, thus indirectly causing the catastrophic flooding that occurred over Algeria on 10 and 11 November and caused the death of almost a thousand people.

In order to confirm the classification of this system as a bomb, Fig. 4 shows the development of the bomb's minimum sea-level pressure from 5 to 12 November. At any time, the

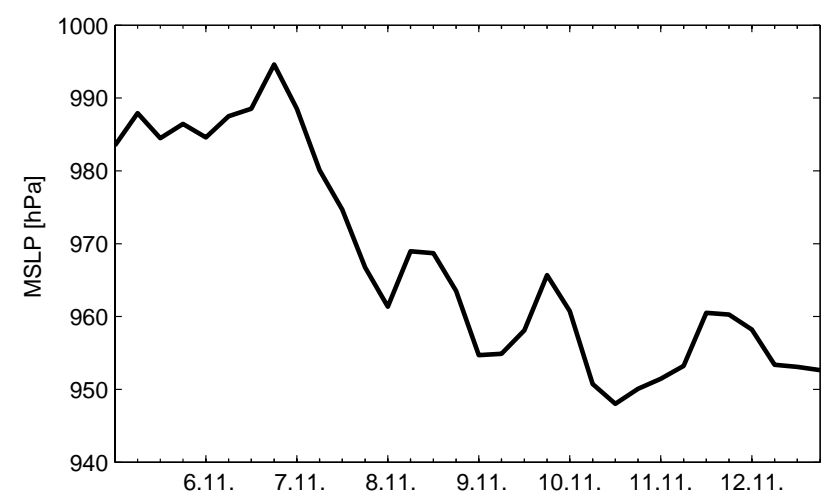

Fig. 4. Minimum sea-level pressure from ECMWF analyses in the core of the bomb during the period 5-12 November 2001 at sixhourly intervals.

minimum sea-level pressure was taken from the core of the deepest of the four systems, "Hu", "C0", "B1", and "B2", respectively (compare Fig. 2). During the 30 -hour period from 6 November 18 UTC to 8 November 0 UTC, the bomb's core pressure decreased from about $995 \mathrm{hPa}$ (in the center of the remnant of "Hu") to $961 \mathrm{hPa}$. This pressure drop of $34 \mathrm{hPa}$ / 30 hours clearly exceeds the criterion $(21 \mathrm{hPa} / 24$ hours at $50^{\circ} \mathrm{N}$ ) defined in SG1980 for explosive cyclogenesis. The bomb criterion was also met according to the 6-hourly Aviation (AVN) model analyses, obtained from the National Center for Enviromental Prediction (NCEP), where the system's central pressure fell from about $997 \mathrm{hPa}$ to $964 \mathrm{hPa}$ during the same time period. The pressure rise on 9 November and the subsequent further drop on 10 November (Fig. 4) are associated with the lysis of "B1" and the genesis of "B2". If pressure were not taken from the center of "B1", "B2" itself would have been classified as a bomb. However, the two systems are not truly independent, as the strong zonal flow generated by "B1" over southern Greenland facilitated the lee cyclogenesis of "B2". Therefore, and for the sake of simplicity, "B1" and "B2" are referred to here as a single bomb.

As will be seen later, the strong zonal flow south of the bomb's center on 9 (Fig. 2e) and 10 (Fig. 2f) November was responsible for the extremely rapid transport of pollution from North America to Europe. Thus, the bomb created an "express highway" for the pollution, visualized by the dense contour lines of both sea-level pressure and $500 \mathrm{hPa}$ geopotential (Fig. 2e-f). It is also important that the bomb itself travelled rapidly to the east, such that the highway was "rolled out", like a carpet, in front of the pollution plume, and was "rolled in" after the plume's passage, enabling rapid transport across the entire Atlantic, even though the highway did not stretch across the entire Atlantic at any particular time. However, the initial export of the pollution from the ABL over North America and its injection into the highway occurred through another system over the Great Lakes region, upstream of the bomb. 

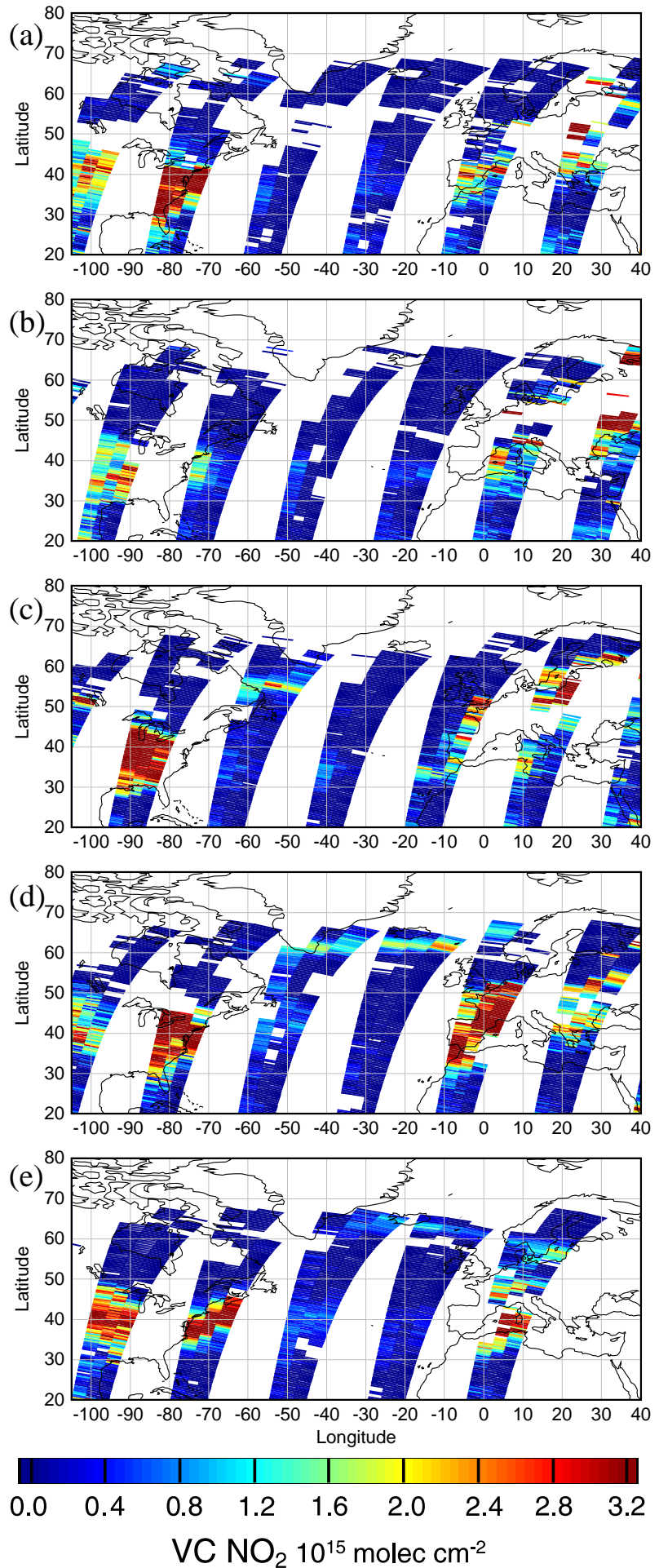

a) 7 November 16 UTC

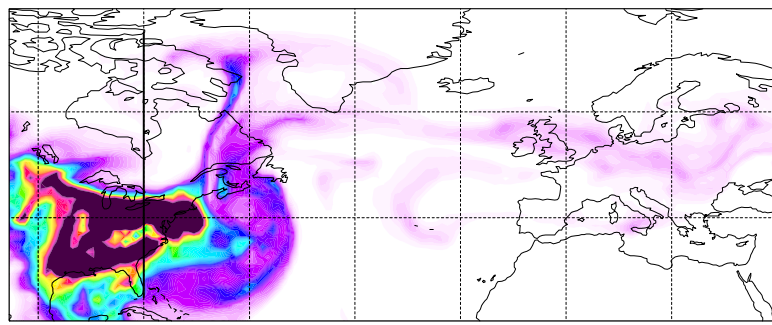

b) 8 November 16 UTC

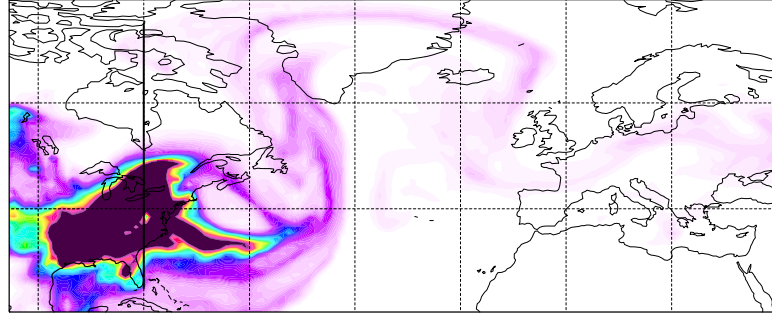

c) 9 November 15 UTC

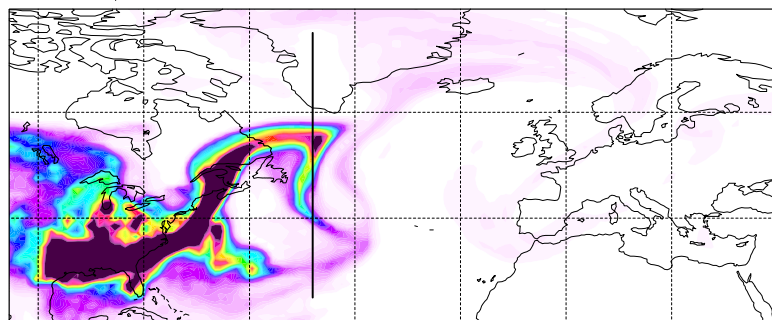

d) 10 November 11 UTC

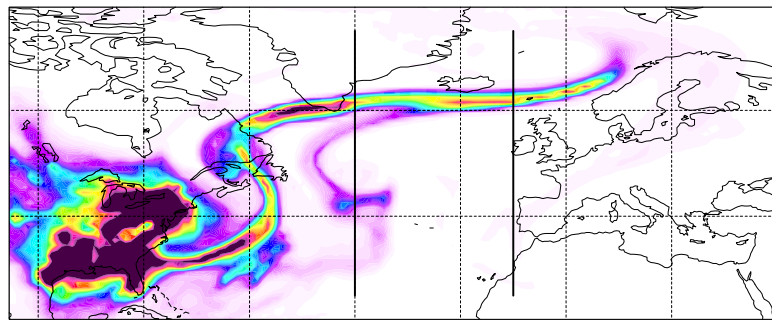

e) 11 November 8 UTC

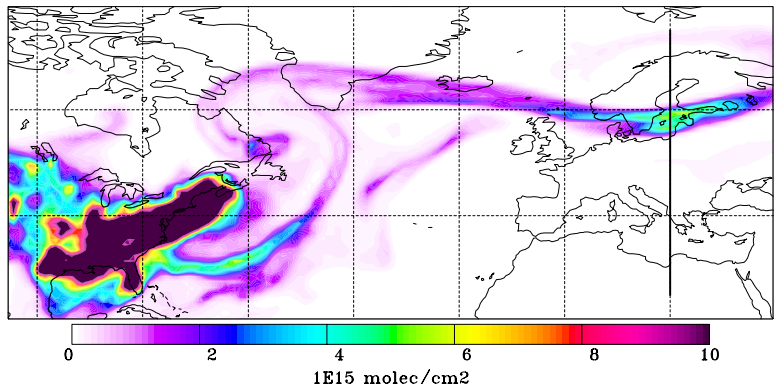

Fig. 5. Tropospheric vertical columns of $\mathrm{NO}_{2}$ (in $10^{15}$ molecules $\mathrm{cm}^{-2}$ ), retrieved from GOME spectral data on (a) 7, (b) 8, (c) 9, (d) 10, and (e) 11 November 2001. White regions indicate that data are missing either because no GOME overpass was available, or because of more than $50 \%$ cloud cover.

Fig. 6. Total vertical columns of the FLEXPART $\mathrm{NO}_{\mathrm{x}}$ tracer (in $10^{15}$ molecules $\mathrm{cm}^{-2}$ ) on (a) 7 , (b) 8 , (c) 9 , (d) 10 , and (e) 11 November. The columns are averages over 1-hour periods ending at $16,16,15,11$, and $8 \mathrm{UTC}$, respectively. Bold black lines mark meridional sections shown in Fig. 7. 
During the days preceding the $\mathrm{NO}_{\mathrm{x}}$ export, eastern North America was under the influence of an anticyclone, which extended from Mexico north to the Hudson Bay. The anticyclone weakened on 5 November, but can still be seen in the pressure charts for 6 November at 0 UTC (Fig. 2a) and 18 UTC (Fig. 2b), where it is labeled "A". Upstream of the bomb "B1", yet another, much weaker, cyclonic system "C2" formed after the retreat of anticyclone "A". On 8 November 0 UTC (Fig. 2c), this system appears as a weak minimum west of the Great Lakes on the surface pressure analysis. 18 hours later (Fig. 2d), "C2" had crossed the Great Lakes and had intensified. The cold frontal cloud band associated with "C2" extended from the Central United States to northeast of the Great Lakes (see Fig. 3), and a sequence of radar images shows a squall line progressing east. Trajectories started at $500 \mathrm{~m}$ above ground level southwest of the Great Lakes on 8 November 0 UTC ascended into the higher-level clouds northeast of the Great Lakes at 18 UTC (not shown). This indicates northward and upward transport of air from the ABL into the express highway that was just "rolled out" south of the bomb on 8 November at 18 UTC (Fig. 2d).

\section{2 $\mathrm{NO}_{\mathrm{x}}$ transport in the bomb}

Fig. 5 shows daily tropospheric vertical columns of $\mathrm{NO}_{2}$ during the period 7-11 November, obtained from GOME spectral data. Figure 6 shows corresponding atmospheric vertical columns of the FLEXPART $\mathrm{NO}_{\mathrm{x}}$ tracer during the period 7-11 November, and Fig. 7 shows meridionally oriented vertical sections through the $\mathrm{NO}_{\mathrm{x}}$ tracer field. The daily plots of the model results are shown for times that, in the region of main interest, coincide best with the GOME overpasses at about 10:30 local time.

On 7 November, the FLEXPART model results indicate that pollution outflow from North America was restricted to the region south of the bomb (Fig. 6a). Over the continent, the $\mathrm{NO}_{\mathrm{x}}$ tracer was capped at about $2 \mathrm{~km}$ by the subsidence inversion of the retreating anticyclone "A" (Fig. 7a). Over North America and downwind of it, the GOME tropospheric $\mathrm{NO}_{2}$ vertical columns (Fig. 5a) show a distribution very similar to the FLEXPART results. In particular, no high values are seen over the ocean, except for a region south of the bomb and close to the continent, where pollution outflow took place. However, this outflow did not reach $\mathrm{Eu}-$ rope subsequently and is not discussed further here. Thus, the situation on 7 November can be considered as typical, similar to the $\mathrm{NO}_{2}$ distributions seen in annually averaged GOME results (Leue et al. 2001; Martin et al. 2002; Richter and Burrows 2002). In contrast to GOME $\mathrm{NO}_{2}$, the model $\mathrm{NO}_{\mathrm{x}}$ tracer shows no enhanced values over Europe, because only North American $\mathrm{NO}_{\mathrm{x}}$ was simulated. Maximum GOME $\mathrm{NO}_{2}$ values over North America are on the order of $10^{16}$ molecules $\mathrm{cm}^{-2}$ (off the scale in Fig. 5a), somewhat less but on a similar order of magnitude as the FLEXPART $\mathrm{NO}_{\mathrm{x}}$ tracer columns over North America. The overprediction is expected, because FLEXPART simulates the sum of NO plus $\mathrm{NO}_{2}$, and because the assumed lifetime of 2 days is too long for conditions in the ABL.

On 8 November, the cyclone "C2" had intensified (Fig. 2d) and a $\mathrm{NO}_{\mathrm{x}}$ plume ascended slantwise with the cyclone's WCB northeast of the Great Lakes (Fig. 7b). Note that, at this time, the $\mathrm{NO}_{\mathrm{x}}$ was contained in the WCB clouds (compare Fig. 6b with Fig. 3). Therefore, and because ERS-2 did not overpass the entire critical region over the Great Lakes, GOME observes little of the $\mathrm{NO}_{2}$ transport (Fig. 5b) on 8 November.

On 9 November, a filament of enhanced $\mathrm{NO}_{\mathrm{x}}$ left North America, with the leading edge of the filament south of Greenland at 15 UTC (Fig. 6c). The corresponding vertical section (Fig. 7c) shows that the main part of the $\mathrm{NO}_{\mathrm{x}}$ tracer plume was located between about 4 and $6 \mathrm{~km}$. At that time, the plume's leading edge had already emerged from the WCB (corresponding satellite images show clouds dissolving in this region), thus giving GOME the first clear opportunity to monitor the $\mathrm{NO}_{\mathrm{x}}$ export from North America. As shown in Fig. 5c, GOME sees a maximum (about $3 \times 10^{15}$ molecules $\mathrm{cm}^{-2}$ ) northeast of Newfoundland, relatively far from any significant source of $\mathrm{NO}_{\mathrm{x}}$, but exactly where FLEXPART suggested pollution injection into the express highway (Fig. 6c).

On 10 November, both GOME (Fig. 5d) and FLEXPART (Fig. 6d) show a filament of enhanced $\mathrm{NO}_{2}$ and $\mathrm{NO}_{\mathrm{x}}$ tracer, respectively, stretching from Newfoundland across the Atlantic almost to Scandinavia. According to FLEXPART, the leading tip of the $\mathrm{NO}_{\mathrm{x}}$ tracer filament had travelled from south of Greenland to Scandinavia, more than $50^{\circ}$ of longitude (or almost $3000 \mathrm{~km}$ at $60^{\circ} \mathrm{N}$ ) in only 20 hours, equivalent to average wind speeds above $40 \mathrm{~m} \mathrm{~s}^{-1}$. Age spectra of the $\mathrm{NO}_{\mathrm{x}}$ tracer (see Stohl et al., 2003, for an explanation how age spectra were obtained from FLEXPART) suggest that most of the $\mathrm{NO}_{\mathrm{x}}$ in the leading part of the filament northeast of Great Britain was emitted in North America 23 days before, but a significant fraction was even younger than 2 days.

Meridional cross-sections through the FLEXPART output show that the filament was located at altitudes of $4-6 \mathrm{~km}$ at $40^{\circ} \mathrm{W}$ (Fig. 7d) and $2-4 \mathrm{~km}$ at $10^{\circ} \mathrm{W}$ (Fig. 7e). The plume, thus, descended from its higher altitude on the previous day (compare with Fig. 7c). Due to the descent clouds evaporated, exposing the plume to the GOME instrument. An infrared satellite image (Fig. 8) confirms that clouds were thin or absent at the plume's location.

The highest $\mathrm{NO}_{2}$ values observed by GOME in the filament between Iceland and Scotland were $2.5 \times 10^{15}$ molecules $\mathrm{cm}^{-2}$. Assuming that the filament's vertical extension was $2 \mathrm{~km}$ (Fig. 7e), simple arithmetics yields an average concentration of $1.0 \mu \mathrm{g} \mathrm{m}^{-3} \mathrm{NO}_{2}$, corresponding to almost $1 \mathrm{ppbv}$ at about $4 \mathrm{~km}$ altitude, within the plume. Assuming that $\mathrm{NO}$ contributes $50 \%$ to the $\mathrm{NO}_{\mathrm{x}}$, average $\mathrm{NO}_{\mathrm{x}}$ concentrations in the plume can be estimated at nearly 2 ppbv, in 

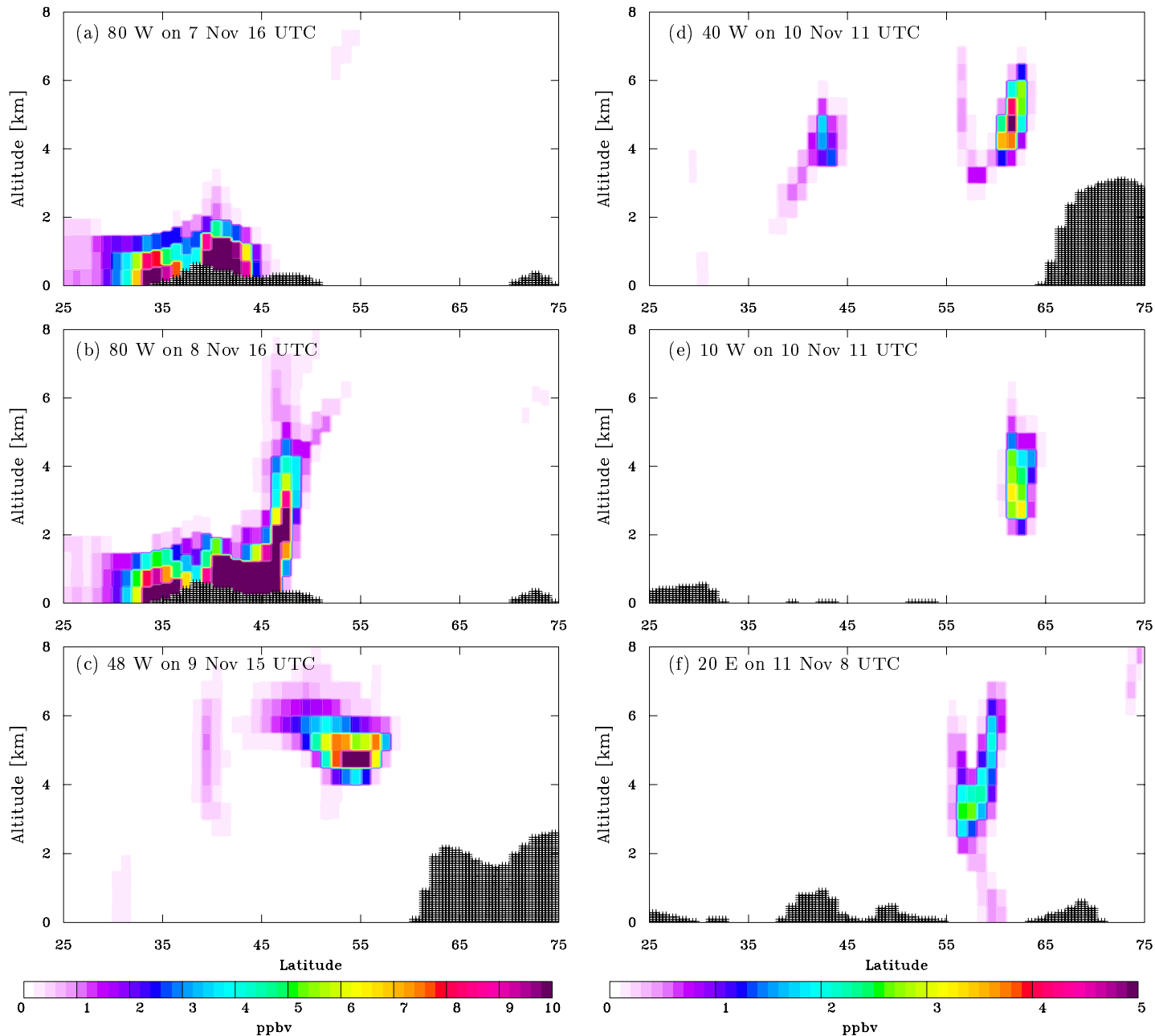

Fig. 7. Meridional cross-sections through the FLEXPART $\mathrm{NO}_{\mathrm{x}}$ tracer (in ppbv) (a) along $80^{\circ} \mathrm{W}$ on 7 November at $16 \mathrm{UTC}$, (b) along $80^{\circ}$ $\mathrm{W}$ on 8 November at $16 \mathrm{UTC}$, (c) along $48^{\circ} \mathrm{W}$ on 9 November at $15 \mathrm{UTC}$, (d) along $40^{\circ} \mathrm{W}$ on 10 November at $11 \mathrm{UTC}$, (e) along $10^{\circ} \mathrm{W}$ on 10 November at $11 \mathrm{UTC}$, (f) along $20^{\circ} \mathrm{E}$ on 11 November at 8 UTC. Hatched areas indicate topography. Note the difference in the $\mathrm{NO}_{\mathrm{X}}$ scale between the left and right column of figures.

good agreement with the $\mathrm{NO}_{\mathrm{x}}$ tracer mixing ratios obtained from the model simulation (Fig. 7e). These are very high $\mathrm{NO}_{\mathrm{x}}$ mixing ratios in the free troposphere, which, given sufficient supply with hydrocarbons (which are likely strongly enhanced in the plume, too) and sunlight, can lead to considerable $\mathrm{O}_{3}$ production.

On 11 November, the main part of the FLEXPART filament extended from southern Greenland to Russia (Fig. 6e). The maximum vertical columns were lower than before, both because of the further decay of the $\mathrm{NO}_{\mathrm{x}}$ tracer, and because the filament broadened, due to mixing with ambient air. Nevertheless, GOME was still able to see the $\mathrm{NO}_{2}$ signal, showing a band of enhanced $\mathrm{NO}_{2}$ values between Greenland and the Baltic Sea (Fig. 5e). The maximum within the band was detected over the Baltic Sea, at the same location where FLEXPART suggested the $\mathrm{NO}_{\mathrm{x}}$ tracer maximum. The cross- sections through the FLEXPART output (Fig. 7f) indicates that the vertical extension of the plume had increased considerably. In the simulation, some of the $\mathrm{NO}_{\mathrm{x}}$ tracer even touched down to the Baltic Sea surface.

\subsection{Cloud effects on the GOME observations}

Considering the potential influence of clouds on the $\mathrm{NO}_{2} \mathrm{ob}-$ servations by GOME (and, thus, uncertainties in the vertical $\mathrm{NO}_{2}$ columns retrieved), two major effects have to be considered: a) $\mathrm{NO}_{2}$ below or deep inside the cloud is shielded, and b) $\mathrm{NO}_{2}$ (directly) above the cloud is enhanced. Thus, it is not a priori clear whether clouds lead to an over- or underestimation of the $\mathrm{NO}_{2}$. In order to correctly account for these effects, the exact vertical distributions of both clouds and $\mathrm{NO}_{2}$ would have to be known at an accuracy that cannot 


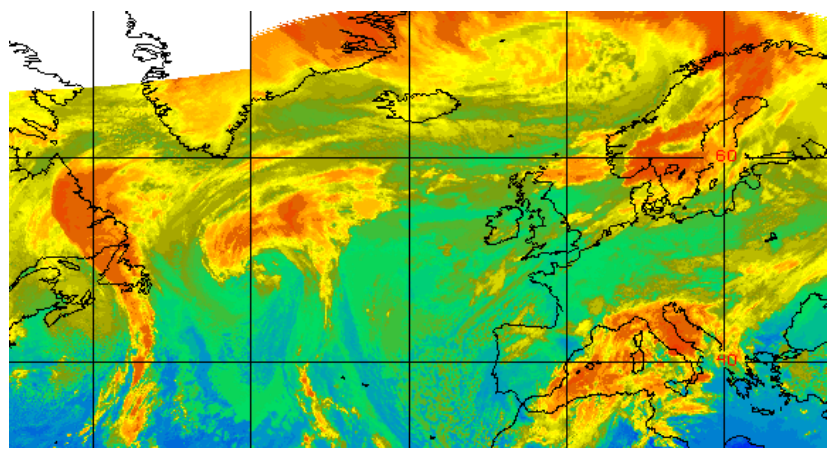

Fig. 8. Combined GOES-East and METEOSAT infrared satellite image on 10 November at 12 UTC. White areas in the northwest corner are regions without data.

be achieved using the data at our disposal. Therefore, we carried out a sensitivity study for a worst-cases scenario for effect b), assuming a thin $\mathrm{NO}_{2}$ layer immediately above a layer of clouds at $3-5 \mathrm{~km}$ altitude. This scenario yields an overestimate of $\mathrm{NO}_{2}$ by our retrieval algorithm of less than a factor of 2, not enough to explain the observed $\mathrm{NO}_{2}$ plume. Note also that, due to the cloud masking, maximum actual cloud cover in the pixels shown is $50 \%$, thus reducing this maximum possible cloud effect. An independent argument against a large $\mathrm{NO}_{2}$ overestimate due to clouds is that the strongest $\mathrm{NO}_{2}$ signals are not seen above the densest clouds, but over pixels with relatively little cloud cover.

Even though the exact vertical distribution of clouds and $\mathrm{NO}_{2}$ are both unknown, it is very likely that clouds formed in the very same airmass that was lifted from the surface and contained the $\mathrm{NO}_{\mathrm{x}}$. Thus, most of the $\mathrm{NO}_{\mathrm{x}}$ would likely be in-cloud, rather than above-cloud. In this case, effect a) could even have lead to an underestimate of the $\mathrm{NO}_{2}$ columns.

\subsection{Confirmation of the anthropogenic origin of the $\mathrm{NO}_{\mathrm{x}}$}

Many previous studies (e.g., Brunner et al. 1998; Wenig et al. 2002) had difficulties with the unambiguous attribution of observed upper tropospheric $\mathrm{NO}_{\mathrm{x}}$ plumes to anthropogenic surface emissions, because the uplift of anthropogenic pollution was associated with strong lightning activity, which can produce additional $\mathrm{NO}_{\mathrm{x}}$ (e.g., Jeker et al., 2000). In this case, too, the vertical transport in cyclone " $\mathrm{C} 2$ " occurred in precipitating clouds, where lightning is possible. However, this episode occurred late in the year, when lightning activity is close to its minimum in the middle latitudes. In order to reliably exclude lightning as the source of the observed $\mathrm{NO}_{\mathrm{x}}$, access was obtained to the lightning data from the Canadian Lightning Detection Network and the U.S. National Lightning Detection Network (NLDN) (Cummins et al., 1998). These networks detect electromagnetic signals from cloudto-ground (CG) lightning discharges. The flash detection efficiency is about $80-90 \%$ over the continent (Cummins et al., 1998), but decreases with distance from the coast over the sea. Flash locations and times were obtained from the U.S. NLDN for the region north of $40^{\circ} \mathrm{N}$ and east of $100^{\circ} \mathrm{W}$, covering the region where the $\mathrm{NO}_{\mathrm{x}}$ was injected into the express highway, for the period 7-10 November 2001. Furthermore, a summary image showing all lightning flashes detected by both the Canadian and the U.S. networks was received (T. Turner, personal communication).

Few lightning flashes were detected over Canada, but a lightning episode was observed over the U.S., and another one off the coast of North America (Fig. 9). During the first episode, from 7 November 12 UTC to 8 November 12 UTC, 807 lightning flashes were detected in the Great Lakes region, which were associated with a line of isolated convective cells seen in a corresponding satellite image. The second lightning episode occurred off the coast of North America on 9 and 10 November, when 4097 lightning flashes were detected north of $40^{\circ} \mathrm{N}$. Since the detection efficiency of the NLDN decreases over the sea, the number of flashes in this region may have been considerably underestimated. Furthermore, no data south of $40^{\circ} \mathrm{N}$ were available.

The data shown in Fig. 9 were used to make an upper estimate of the lightning $\mathrm{NO}_{\mathrm{x}}$ emissions on the basis of emission factors reported in the literature. This estimate then served as an input for a FLEXPART lightning $\mathrm{NO}_{\mathrm{x}}$ tracer simulation, in order to judge whether lightning could have contributed significantly to the $\mathrm{NO}_{\mathrm{x}}$ plume detected by GOME or not. First it must be considered that the NLDN detects only CG lightning discharges, but no intracloud (IC) flashes. The ratio of IC/CG flashes over the Great Lakes region varies from 2 to 7 (Boccippio et al., 2001). Taking the higher value, it was assumed that 5649 and 28679 IC flashes occurred in the two lightning clusters (7 at each position of a CG flash).

Before estimating the $\mathrm{NO}_{\mathrm{x}}$ production, the vertical distribution in the cloud of the lightning $\mathrm{NO}_{\mathrm{x}}$ must be considered. Pickering et al. (1998) suggested that the downdrafts carry about $23 \%$ of the total $\mathrm{NO}_{\mathrm{x}}$ produced from lightning, which results mostly from CG flashes, while updrafts carry $77 \%$ of the $\mathrm{NO}_{\mathrm{x}}$, produced by both IC and CG flashes. Here it is assumed that downdrafts released the $\mathrm{NO}_{\mathrm{x}}$ between the surface and $1 \mathrm{~km}$ above, while updrafts released it between 6 and $10 \mathrm{~km}$, the approximate altitude of the highest cloud tops according to satellite infrared imagery.

Values reported in the literature for the $\mathrm{NO}_{\mathrm{x}}$ produced per cloud-to-ground lightning flash vary considerably, for instance $6.7 \times 10^{26}$ molecules flash $^{-1}$ (Price et al., 1997), $1.25-12.5 \times 10^{25}$ molecules flash $^{-1}$ (Stith et al., 1999), or $8.1 \times 10^{25}$ molecules flash $^{-1}$ (Huntrieser et al., 2002). DeCaria et al. (2000) estimated that $3 \times 10^{26}$ molecules CGflash $^{-1}$ are carried by the downdrafts. Taking this last value, which is at the upper range of the more recent values reported in the literature, and assuming a $80 \%$ detection efficiency of CG flashes (note that this value may be too low for the second episode), it is estimated that $23.3 \mathrm{t} \mathrm{NO}_{2}$ were produced in the first lightning episode below $1 \mathrm{~km}$, and $118 \mathrm{t} \mathrm{NO}_{2}$ in the second episode. 


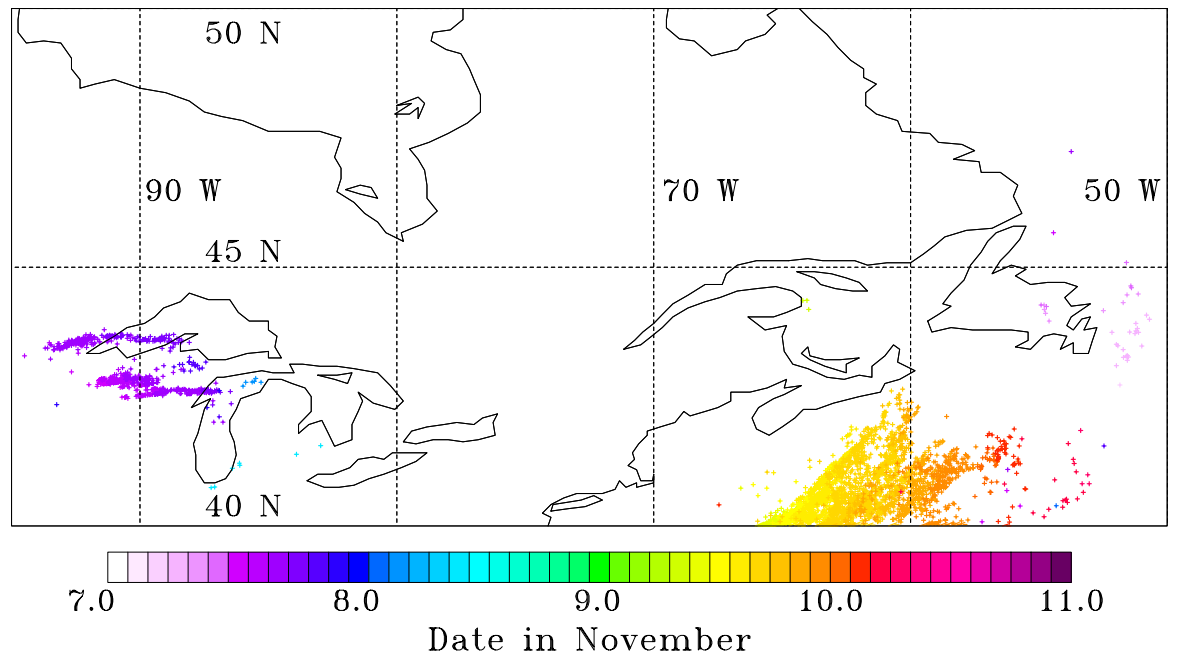

Fig. 9. Locations of lightning flashes detected by the U.S. National Lightning Detection Network during the period from 7 November 0 UTC to 11 November 0 UTC. The color of the plusses indicates the time of lightning.

IC flashes produce less $\mathrm{NO}_{\mathrm{x}}$ per flash than $\mathrm{CG}$ flashes (Price et al., 1997). DeCaria et al. (2000) estimate that $1.4 \times 10^{26}$ molecules IC-flash ${ }^{-1}$ and $3 \times 10^{26}$ molecules CGflash $^{-1}$ are carried in updrafts. Adopting these values results in a $\mathrm{NO}_{2}$ release between 6 and $10 \mathrm{~km}$ of $98 \mathrm{t} \mathrm{NO}$ for the first episode and $497 \mathrm{t} \mathrm{NO}_{2}$ for the second episode, if again $80 \%$ detection efficiency for CG flashes is assumed.

These values can be compared to emissions of $49,000 \mathrm{t}$ $\mathrm{NO}_{2}$ per day in the entire U.S., and $880 \mathrm{t} \mathrm{NO}_{2}$ per day in a single $1^{\circ} \times 1^{\circ}$ grid cell over Chicago, according to the EDGAR inventory (Olivier and Berdowski, 2001). Thus, both lightning episodes seem to be negligible sources of $\mathrm{NO}_{\mathrm{x}}$ compared to the anthropogenic source. However, as most of the lightning $\mathrm{NO}_{\mathrm{x}}$ is transported to the anvil region, where the $\mathrm{NO}_{\mathrm{x}}$ lifetimes are longer than in the $\mathrm{ABL}$, a much larger fraction than of the anthropogenic $\mathrm{NO}_{\mathrm{x}}$ may be available to long-range transport. Therefore, two lightning $\mathrm{NO}_{\mathrm{x}}$ tracers were simulated with FLEXPART, one for each of the two episodes, assuming a $\mathrm{NO}_{\mathrm{x}}$ lifetime of 2 days.

Fig. 10 shows, for both lightning clusters, the total vertical columns of the lightning $\mathrm{NO}_{\mathrm{x}}$ tracer at the time of the GOME observations on 10 November. It is seen that a part of the $\mathrm{NO}_{\mathrm{x}}$ produced by the first lightning cluster indeed travelled in the express highway (Fig. 10a), approximately where GOME detected the $\mathrm{NO}_{2}$ filament. However, the maximum vertical columns in this region were only about $5 \times 10^{12}$ molecules $\mathrm{cm}^{-2}$, or more than two orders of magnitude less than the observed $\mathrm{NO}_{2}$. Most of the lightning $\mathrm{NO}_{\mathrm{x}}$ tracer (it can be shown that it was the part released in the anvil) was located over the central North Atlantic, but even there $\mathrm{NO}_{\mathrm{x}}$ columns were too low to be detectable by GOME.

The maximum $\mathrm{NO}_{\mathrm{x}}$ tracer columns resulting from the second lightning cluster (Fig. 10b) were much higher than those from the first one, but on 10 November the plume was still quite close to where it had been produced. Part of this plume was injected into the express highway and travelled to $\mathrm{Eu}-$ rope subsequently, but too late to explain more than the trailing end of the GOME filament observed on 11 November. Therefore, lightning $\mathrm{NO}_{\mathrm{x}}$ emissions from the second cluster also cannot explain the GOME observations, especially not on 10 November. Unfortunately, in this case, the NLDN may have missed lightning further off-shore, because of the decrease in detection efficiency with distance from the coast. Furthermore, no lightning data were available south of $40^{\circ}$ $\mathrm{N}$. Therefore, we repeated the FLEXPART simulations two times, first shifting the emissions $5^{\circ}$ to the east and, second, $5^{\circ}$ to the south. Neither of these sensitivity simulations could explain the GOME observations.

Finally, it was explored whether the $\mathrm{NO}_{\mathrm{x}}$ could have been produced by lightning in the hurricane, where the Lightning Imaging Sensor (LIS) detected some lightning flashes. For this, we released lightning tracers at the hurricane's approximate location in maps of sea-level pressure on 2, 3, and 4 November. In all three cases, the tracers were advected eastwards across the Atlantic Ocean, but at latitudes of approximately $40-50^{\circ} \mathrm{N}$ and rather slowly. GOME did not see enhanced $\mathrm{NO}_{2}$ along these pathways. None of the three lightning tracers was transported in the express highway. According to LIS and NLDN data, no other major lightning activity was observed close to the region of inflow into the express highway during the days preceding the event. Therefore, lightning can be ruled out to the best of our knowledge as the main source of the $\mathrm{NO}_{2}$ detected by GOME. 
a) 10 November 11 UTC, lightning cluster 1

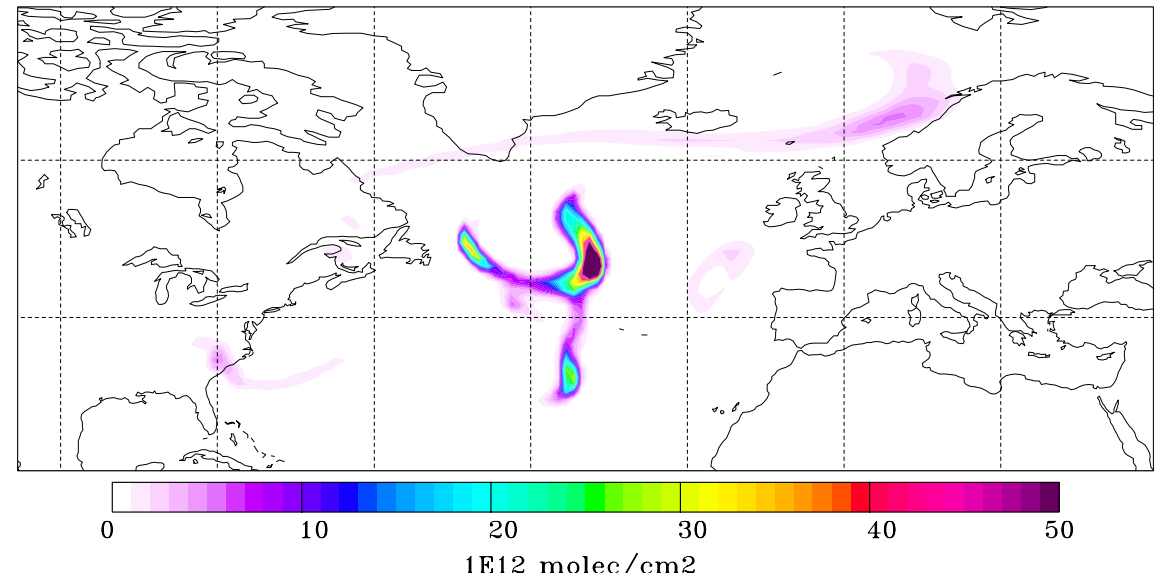

b) 10 November 11 UTC, lightning cluster 2

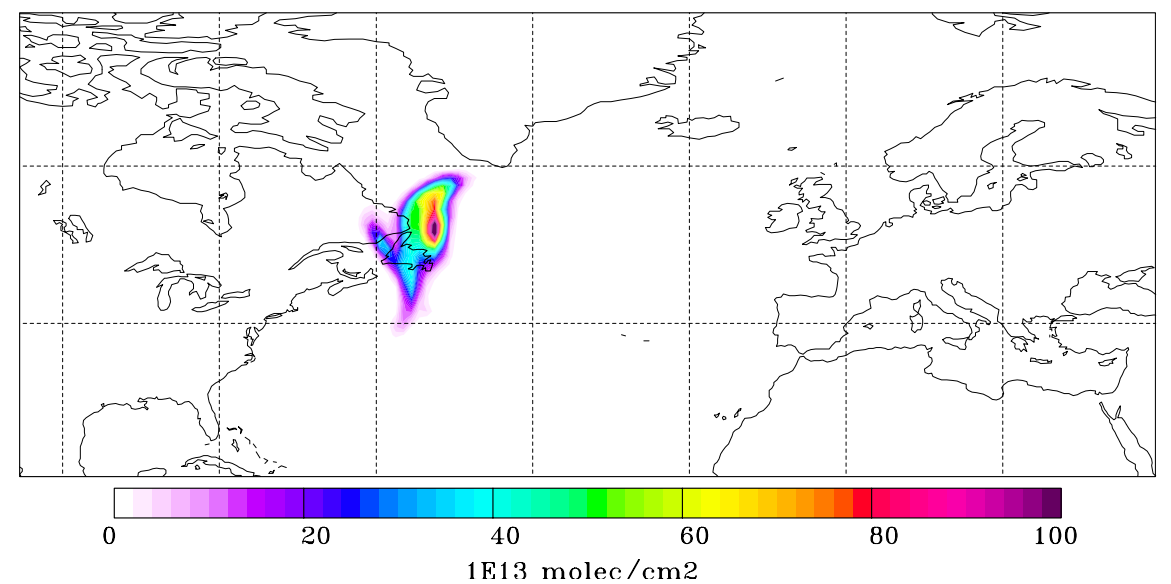

Fig. 10. Total vertical columns of the FLEXPART lightning $\mathrm{NO}_{\mathrm{x}}$ tracer on 10 November at 11 UTC for (a) lightning cluster 1 (in $10^{12}$ molecules $\mathrm{cm}^{-2}$ ), and (b) lightning cluster 2 (in $10^{13}$ molecules $\mathrm{cm}^{-2}$ ).

\section{Discussion and climatological considerations}

In this paper it was shown, unambiguously for the first time, that $\mathrm{NO}_{\mathrm{x}}$ from anthropogenic sources can be transported over intercontinental distances. More than $1 \mathrm{ppbv} \mathrm{NO}_{\mathrm{x}}$ arrived over Europe within the North American plume, bearing significant capacity for $\mathrm{O}_{3}$ formation. The key transport mechanism in this episode, strong zonal flow south of the center of a meteorological bomb, was quite exceptional and has not yet been studied in the context of atmospheric chemistry. The question, thus, arises, whether this was just an interesting event at the very extreme end of the spectrum of all transport events, or whether similar episodes do indeed happen more often. In other words: What is the climatological relevance of air pollution transport in bombs?

It is not straightforward to use GOME data for answering this question, because normally the upward transport of pollution is accompanied by extensive cloud formation, shield- ing $\mathrm{NO}_{2}$ from the satellite's view. In the case presented here the clouds dissolved quickly after their formation, but this is likely not a typical situation. Furthermore, the longer lifetime of $\mathrm{NO}_{\mathrm{x}}$ in winter than in summer favored the long-range transport of $\mathrm{NO}_{\mathrm{x}}$ in this case, and the $\mathrm{NO}_{\mathrm{x}}$ partitioning between $\mathrm{NO}$ and $\mathrm{NO}_{2}$ shifts towards $\mathrm{NO}_{2}$ in winter, again favoring the plume's detection by GOME. In addition, lightning may sometimes contribute a large fraction of the $\mathrm{NO}_{\mathrm{x}}$ (at least in summer), rendering difficult the attribution of the detected $\mathrm{NO}_{\mathrm{x}}$ to an anthropogenic source.

An answer to the above question can be given on the basis of bomb climatologies. SG1980 identified 109 and 158 bombs in the North Atlantic and North Pacific in three winter half years (maximum frequency in January), respectively, but they note that, for several reasons, bombs are underreported in their study. Similar frequencies were also reported by Roebber (1984) for another 1-year period. Using somewhat stronger criteria for bomb classification, 
Lim and Simmonds (2002) found 46 and 26 bomb events per year in the Northern and Southern Hemisphere, respectively. However, they only considered explosive developments starting at $0 \mathrm{UTC}$, thus underestimating true bomb frequencies. Furthermore, all three studies used coarse-resolution meteorological data, where not all bombs could be detected. Therefore, on a global scale bombs are quite frequent phenomena. On average, a bomb event occurs about once a week on the Northern Hemisphere, and this frequency increases to one event every two days at the peak of the winter-time bomb season.

Both SG1980 and Lim and Simmonds (2002) found the highest bomb frequencies over the warm Kuroshio current and Gulf stream east of Asia and North America, respectively (see Fig. 3 in SG1980 and Fig. 12 in Lim and Simmonds, 2002), but detected few bombs over land. For the Southern Hemisphere, Lim and Simmonds (2002) report the highest bomb frequencies at about $60^{\circ} \mathrm{S}$, relatively remote from pollution sources (albeit secondary maxima were detected downwind of South America and Australia). Taking this together with the lower overall bomb frequency, it seems that bombs are not a particularly relevant factor for air pollution transport on the Southern Hemisphere. On the Northern Hemisphere, however, bombs may influence transport of Asian and North American pollution to a significant extent. In contrast, bombs are negligible for transport of European pollution.

Another way to estimate the climatological relevance of bombs is to look at the frequency of express highways in transport climatologies. While fast transport is not necessarily associated with bombs only, it can be argued that a large fraction of the fastest intercontinental transport events is associated either with bombs or at least with cyclones that, albeit not quite fulfilling the bomb criterion of rapid deepening, are of extreme intensity. Note, though, that fast transport in the upper troposphere can also occur with a jet streak without involving a bomb. Therefore, in order to avoid ambiguities, the original question posed at the beginning of this discussion can be changed to: What is the climatological relevance of air pollution transport in intercontinental express highways?

Stohl et al. (2002a) presented a 1-year climatology of the pathways and timescales of ICT, which has been extended recently by Eckhardt et al. (2003) to a 15 -year period, and which is used here to answer the above question. For the climatology, FLEXPART was used to calculate the global transport of six passive continental tracers. Tracer particles were released over the continents according to the emission distribution of carbon monoxide continuously throughout the entire 15-year simulation (to convert to $\mathrm{NO}_{\mathrm{x}}$, we have to assume typical emission ratios for the two species, see below). Particles were advected for 50 days, after which they were removed from the simulations. The model output was organized in 12 age classes (denoting time after emission), the first three ones being 0-2, 2-4, and 4-6 days, and the last one being 40-50 days. An infinite tracer lifetime was used in the simulations, but tracer decay can be approximately determined for any lifetime using the discrete age class information available in the model output. For details of the transport climatology, the reader is referred to the papers of Stohl et al. (2002a) and Eckhardt et al. (2003).

Given the above age classes, a subjective definition for intercontinental express highways is that the North America tracer arrives over Europe within less than 4 days. Note that in the case study, the bulk of the $\mathrm{NO}_{\mathrm{x}}$ would have fulfilled this criterion. For transport from Asia to North America, the greater dimension of the Pacific Ocean must be considered. Furthermore, it is not very likely for a cyclone (and presumably also not for a bomb) to track across the whole Pacific (Hoskins and Hodges, 2002). Therefore, 6 days are used as the limit for an express highway between Asia and North America.

Figure 11 shows cumulative age spectra of the concentrations of the North America tracer and of the Asia tracer, averaged over meridionally oriented vertical planes at the west coasts of the respective downwind continent (Europe for the North America tracer, North America for the Asia tracer). It can be seen that the tracer concentrations increase by orders of magnitude as transport time increases. This is a result of increasingly slow transport mechanisms being capable of delivering tracer to the downwind continent as the transport time increases. In agreement with the climatology of bombs, express highways are found to be much more important in winter than in summer. On average, express highways, as defined above, deliver about $0.16 \mu \mathrm{g} \mathrm{m}^{-3}$ of tracer from North America to Europe $\left(0.14 \mu \mathrm{g} \mathrm{m}^{-3}\right.$ from Asia to North America) in winter, but only $0.05 \mu \mathrm{g} \mathrm{m}^{-3}\left(0.03 \mu \mathrm{g} \mathrm{m}^{-3}\right)$ in summer. In contrast, in both seasons and for both tracers, about $10 \mu \mathrm{g} \mathrm{m}^{-3}$ of tracer are delivered to the downwind continent up to a timescale of 50 days. Therefore, in winter express highways contribute only about $1-2 \%$ of the tracer that is delivered within 50 days, and in summer even only $0.3-0.5 \%$. This makes it immediately clear that express highways bear little climatological significance for trace substances with lifetimes of the order of ten days or more.

The situation is different for trace substances with a shorter lifetime. For instance, Fig. 12 shows the results if it is assumed that the tracer has a lifetime of only 1 day (note that the values reported are valid only approximately, as the tracer decay had to be estimated from the discrete age spectra). In this case, fast transport events dominate the budgets, and express highways from North America to Europe are responsible for about $65 \%$ of the total tracer transport in winter and $44 \%$ in summer. For express highways from Asia to North America the respective numbers are $75 \%$ in winter and $60 \%$ in summer. Twice as much North American 1-day lifetime tracer arrives over Europe and four times more Asian tracer arrives over North America in winter than in summer.

The absolute values of the tracers delivered with express highways are relatively small, but nevertheless significant. If 


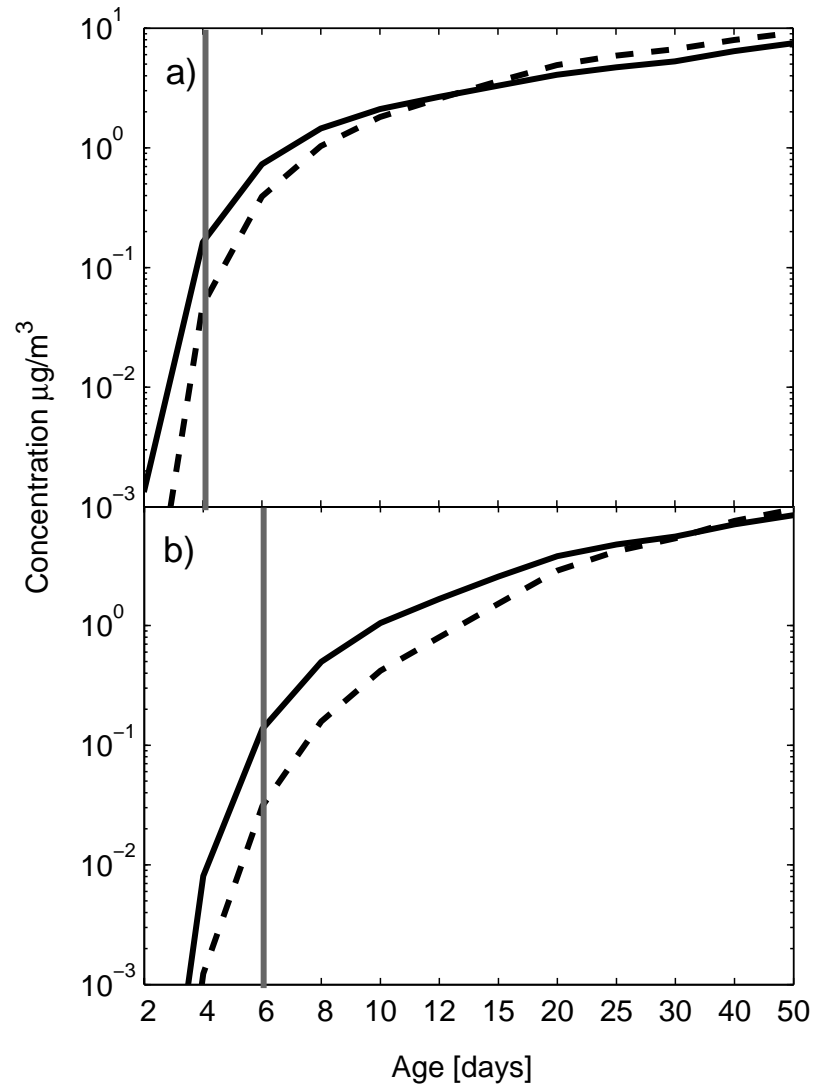

Fig. 11. Cumulative age spectra, averaged over a meridionally oriented vertical (up to $10 \mathrm{~km}$ ) plane, in December, January and February (solid lines) and in June, July and August (dashed lines) of (a) the North America tracer at $0^{\circ} \mathrm{W}$ between $36^{\circ} \mathrm{N}$ and $70^{\circ} \mathrm{N}$, and (b) the Asia tracer at $125^{\circ} \mathrm{W}$ between $20^{\circ} \mathrm{N}$ and $70^{\circ} \mathrm{N}$. Values are plotted at the end of the respective age class interval. Grey vertical lines separate express highways (to the left) from slower modes of transport (to the right).

we assume that $\mathrm{NO}_{\mathrm{x}}$ has an average lifetime of 1 day (note that it may actually be longer in the free troposphere) and, furthermore, the molar ratio of $\mathrm{NO}_{\mathrm{x}}$ and carbon monoxide emissions is 0.16 (a value typical at least for the United States (EPA, 2000), but with relatively large uncertainty (Parrish et al., 2002)), we can use our climatology to estimate the impact of express highways on $\mathrm{NO}_{\mathrm{x}}$ concentrations. Converting carbon monoxide into $\mathrm{NO}_{\mathrm{x}}$ emissions and accounting for differences in molar weights, it can be determined from Fig. 12a that in winter on average about $2.2 \mathrm{ng} \mathrm{m}^{-3}$ $\mathrm{NO}_{\mathrm{x}}$ arrives over Europe with express highways. Depending on the altitude, this translates into $2-3$ pptv $\mathrm{NO}_{\mathrm{x}}$, a very significant fraction of the $10-30$ pptv required to push the photochemical regime from $\mathrm{O}_{3}$ destruction to $\mathrm{O}_{3}$ production in the upper troposphere (Reeves et al., 2002). Certainly, express highways are episodic events, and a mean contribution to the $\mathrm{NO}_{\mathrm{x}}$ is misleading in terms of their impact on $\mathrm{O}_{3}$ formation. However, one can easily imagine that thin filaments,

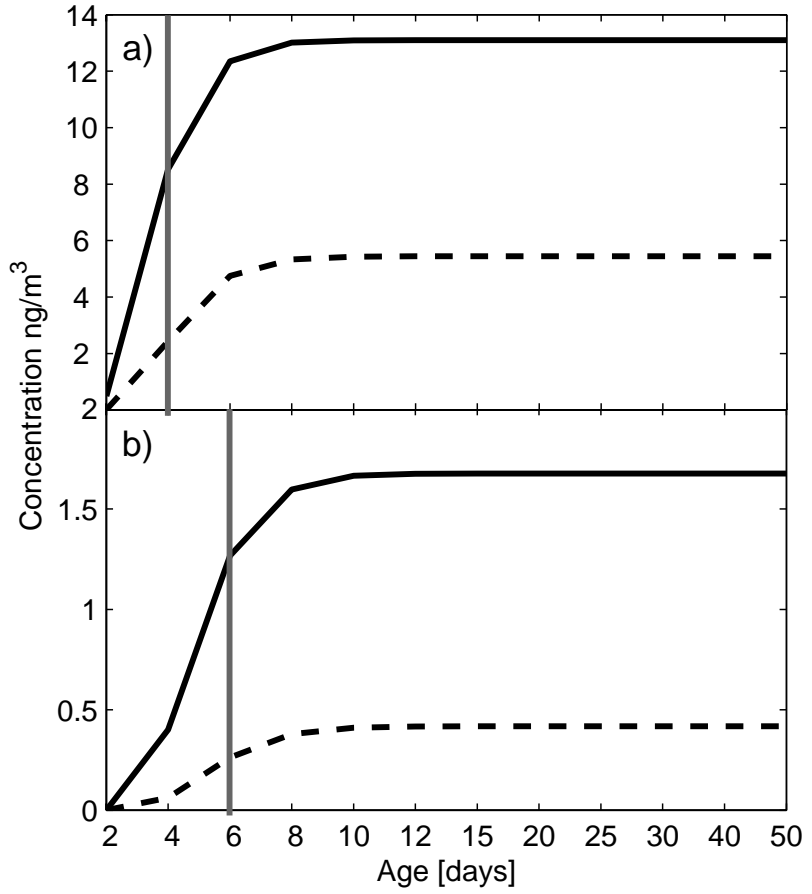

Fig. 12. Same as Fig. 11, but assuming a 1-day lifetime of the tracer. Note that a linear scale is used here, in contrast to Fig. 11

such as the one found in the case study - and as they are typical for rapid transport events -, are mixed into the hemispheric background over short time scales (note that, in the case study, the model simulations actually suggested substantial dilution). Therefore, and because other ozone precursors would be significantly enhanced, too, it may well be the case that air pollution express highways have a significant influence on the chemical budget of the remote Northern Hemisphere troposphere in winter. To further explore this hypothesis, simulations with chemistry transport models are required.

\section{Conclusions}

The conclusions from this study are as follows:

- In a case study, very good agreement between $\mathrm{NO}_{\mathrm{x}}$ tracer plumes simulated by the FLEXPART tracer transport model and GOME $\mathrm{NO}_{2}$ measurements was found.

- For this case study it was shown, unambiguously for the first time, that $\mathrm{NO}_{\mathrm{x}}$ from anthropogenic surface sources can be transported over intercontinental distances. Lightning could definitely be ruled out as the source of the $\mathrm{NO}_{\mathrm{x}}$.

- Within the pollution plume originating from North America, more than $1 \mathrm{ppb} \mathrm{NO}_{\mathrm{x}}$ arrived over western Europe. The fact that $\mathrm{NO}_{\mathrm{x}}$ concentrations in the $\mathrm{ppb}$ 
range can occur so far downwind from the emission source may have implications for the ozone production in remote regions of the troposphere, particularly because they may be accompanied by high concentrations of other substances, including short-lived ones such as olefines and aldehydes.

- Meteorological bombs are a, so far unexplored, transport mechanism of extremely fast long-range air pollution transport. The pathway was termed here an intercontinental express highway.

- Air pollution transport in an intercontinental express highway across the North Atlantic can take as little as one day. The time from the emission of an air pollutant at the surface in North America to its arrival over Europe can be less than two days.

- A 15-year transport climatology shows that intercontinental express highways are by a factor 4 more frequent in winter than in summer, in agreement with bomb climatologies.

- The climatology furthermore indicates that intercontinental express highways bear little climatological relevance for longer-lived substances (e.g., carbon monoxide), but may be important for some short-lived substances. For a substance with a lifetime of 1 day, express highways may account for about two thirds of the total ICT.

- A rough calculation suggests that express highways connecting North America with Europe enhance the climatological mean $\mathrm{NO}_{\mathrm{x}}$ mixing ratio over Europe by about 2-3 pptv in winter. However, actual events are highly episodic and, thus, enhancements vary strongly.

Acknowledgements. This study was part of the projects ATMOFAST, CONTRACE and NOXTRAM, all funded by the German Federal Ministry for Education and Research within the Atmospheric Research Program 2000 (AFO 2000). ECMWF and the German Weather Service are acknowledged for permitting access to the ECMWF archives. The GOES-EAST infrared images were made available through the UNIDATA McIDAS data stream and the METEOSAT images were released by EUMETSAT, and were made available through the NASA Marshall Space Flight Center. GOME 1v1-spectra have been provided by ESA through DLR-DFDOberpfaffenhofen. We express our gratitude to Vaisala-GAI Inc. (T. Turner and R. Zaharescu) for providing data from the U.S. National Lightning Detection Network and a figure showing lightning flashes detected by both the Canadian and the U.S. National Lightning Detection Networks.

\section{References}

Bjerknes, V.: Synoptical representation of atmospheric motions, Q. J. R. Meteorol. Soc., 36, 167-286, 1910.

Boccippio, D. J., Cummins, K. L., Christian, H. J., and Goodman, S. J.: Combined satellite- and surface-based estimation of the intracloud-cloud-to-ground lightning ratio over the continental United States, Mon. Weather Rev., 129, 108-122, 2001.

Bradshaw, J., Davis, D., Grodzinsky, G., Smyth, S., Newell, R., Sandholm, S., and Liu, S.: Observed distributions of nitrogen oxides in the remote free troposphere from the NASA global tropospheric experiment programs, Rev. Geophys., 38, 61-116, 2000.

Browning, K. A., Hardman, M. E., Harrold, T. W., and Pardoe, C. W.: Structure of rainbands within a mid-latitude depression, Q. J. R. Meteorol. Soc., 99, 215-231, 1973.

Brunner, D., Staehelin, J., and Jeker, D.: Large-scale nitrogen oxide plumes in the tropopause region and implications for ozone, Science, 282, 1305-1309, 1998.

Buckley, B. W. and Leslie, L. M.: The Australian Boxing Day storm of 1998 - Synoptic description and numerical simulations, Wea. Forecasting, 15, 543-558, 2000.

Burrows, J. P., Weber, M. Buchwitz, M., Rozanov, V. V., Ladstätter, A., Weißenmayer, Richter, A., DeBeek, R., Hoogen, R., Bramstedt, K., and Eichmann, K. U.: The Global Ozone Monitoring Experiment (GOME): Mission concept and first scientific results, J. Atmos. Sci., 56, 151-175, 1999.

Burt, S. D. and Mansfield, D. A.: The great storm of 15-16 October 1987, Weather, 43, 90-114, 1988.

Carlson, T. N.: Mid-Latitude Weather Systems, American Meteorological Society, Boston, 507 p., 1998.

Cooper, O. R., Moody, J. L., Parrish, D. D., Trainer, M., Ryerson, T. B., Holloway, J. S., Hübler, G., Fehsenfeld, F. C., and Evans, M. J.: Trace gas composition of midlatitude cyclones over the western North Atlantic Ocean: A conceptual model, J. Geophys. Res., 107, doi: 10.1029/2001JD000901, 2002.

Cummins, K. L., Murphy, M. J., Bardo, E. A., Hiscox, W. L., Pyle, R. B., and Pifer, A. E.: A combined TOA/MDF technology upgrade of the U.S. National Lightning Detection Network, J. Geophys. Res., 103, 9035-9044, 1998.

DeCaria, A. J., Pickering, K. E., Stenchikov, G. L., Scala, J. R., Stith, J. L, Dye, J. E., Ridley, B. A., and Laroche, P.: A cloudscale model study of lightning-generated $\mathrm{NO}_{\mathrm{x}}$ in an individual thunderstorm during STERAO-A, J. Geophys. Res., 105, 11 601-11 616, 2000.

Eckhardt, S., Stohl, A., Beirle, S., Spichtinger, N., James, P., Forster, C., Junker, C., Wagner, T., Platt, U., and Jennings, S. G.: The North Atlantic Oscillation controls air pollution transport to the Arctic, submitted to Atmos. Chem. Phys.

ECMWF: User Guide to ECMWF Products 2.1, Meteorological Bulletin M3.2, ECMWF, Reading, UK, 1995.

Emanuel, K. A. and Živković-Rothman, M.: Development and evaluation of a convection scheme for use in climate models, J. Atmos. Sci. 56, 1766-1782, 1999.

EPA: National Air Quality and Emissions Trends Report, 1998, EPA Report, EPA-454/R-00-003, EPA, 2000.

Forster, C., Wandinger, U., Wotawa, G., James, P., Mattis, I., Althausen, D., Simmonds, P., O'Doherty, S., Kleefeld, C., Jennings, S. G., Schneider, J., Trickl, T., Kreipl, S., Jäger, H., and Stohl, A.: Transport of boreal forest fire emissions from Canada to Europe, J. Geophys. Res., 106, 22 887-22 906, 2001. 
Heland, J., Schlager, H., Richter, A., and Burrows, J. P.: First comparison of tropospheric $\mathrm{NO}_{2}$ column densities retrieved from GOME measurements and in situ aircraft profile measurements, Geophys. Res. Lett., doi:10.1029/2002GL015528, 2002.

Hoskins, B. J. and Hodges, K. I.: New perspectives on the Northern Hemisphere winter storm tracks, J. Atmos. Sci. 59, 1041-1061, 2002.

Huntrieser, H., Feigl, C., Schlager, H., et al.: Airborne measurements of $\mathrm{NO}_{\mathrm{x}}$, tracer species and small particles during the European Lightning Nitrogen Oxides Experiment, J. Geophys. Res., 107, 10.1029/2000JD000209, 2002.

Huntrieser, H., Heland, J., Stohl, A., et al.: Intercontinental transport of pollution from North America to Europe: Airborne trace gas measurements over central and northern Europe, in preparation for J. Geophys. Res., 2003.

Jaeglé, L., Jacob, D. J., Wang, Y., et al.: Sources and chemistry of $\mathrm{NO}_{x}$ in the upper troposphere over the United States, Geophys. Res. Lett., 25, 1705-1708, 1998.

Jaffe, D., Anderson, T., Covert, D., et al.: Transport of Asian air pollution to North America, Geophys. Res. Lett., 26, 711-714, 1999.

Jeker, D. P., Pfister, L., Thompson, A. M., Brunner, D., Boccippio, D., Pickering, K. E., Wernli, H., Kondo, Y., and Staehelin, J.: Measurements of nitrogen oxides at the tropopause: Attribution to convection and correlation with lightning, J. Geophys. Res., 105, 3679-3700, 2000.

Lauer, A., Dameris, M., Richter, A., and Burrows, J. P.: Tropospheric $\mathrm{NO}_{2}$ columns: a comparison between model and retrieved data from GOME measurements, Atmos. Chem. Phys., 2, 67-78, 2002.

Lawrence, M., Rasch, J. P., von Kuhlmann, R., et al.: An operational global chemical weather forecast system for field campaign support: Predictions and observations of large-scale features during INDOEX, MINOS, and CONTRACE, Atmos. Chem. Phys. Discuss., 2, 1545-1597, 2003.

Lemaitre, Y., Protat, A., and Scialom, G.: Dynamics of a "bomblike" deepening secondary cyclone from airborne Doppler radar, Q. J. R. Meteorol. Soc., 125, 2797-2818, 1999.

Leue, C., Wenig, M., Wagner, T., Klimm, O., Platt, U., and Jähne, B.: Quantitative analysis of $\mathrm{NO}_{\mathrm{x}}$ emissions from Global Ozone Monitoring Experiment satellite image sequences, J. Geophys. Res., 106, 5493-5505, 2001.

Lim, E.-P. and Simmonds, I.: Explosive cyclone development in the Southern Hemisphere and a comparison with Northern Hemisphere events, Mon. Wea. Rev., 130, 2188-2209, 2002.

Liang, J. Y., Horowitz, L. W., Jacob, D. J., Wang, Y. H., Fiore, A. M., Logan, J. A., Gardner, G. M., Munger, J. W.: Seasonal budgets of reactive nitrogen species and ozone over the United States, and export fluxes to the global atmosphere, J. Geophys. Res., 103, 13 435-13 450, 1998.

Lin, X., Trainer, M., and Liu, S. C.: On the nonlinearity of the tropospheric ozone production, J. Geophys. Res., 93, 15 879-15888, 1988.

Martin, R. V., Chance, K., Jacob, D. J., Kurosu, T. P., Spurr, R. J. D., Bucsela, E., Gleason, J. F., Palmer, P. I., Bey, I., Fiore, A. M., Li, Q., Yantosca, R. M.: An Improved Retrieval of Tropospheric Nitrogen Dioxide from GOME , J. Geophys. Res., 107, 4437, doi:10.1029/2001JD001027, 2002.

Olivier, J. G. J. and Berdowski, J. J. .M.: Global emissions sources and sinks. In: Berdowski, J., Guicherit, R. and B. J. Heij (Eds.), The Climate System, pp. 33-78, A. A. Balkema Publishers/Swets and Zeitlinger Publishers, Lisse, The Netherlands. ISBN 905809255 0, 2001.

Parrish, D. D., Trainer, M., Hereid, D., Williams, E. J., Olszyna, K. J., Harley, R. A., Meagher, J. F., and Fehsenfeld, F. C.: Decadal change in carbon monoxide to nitrogen oxide ratio in U.S. vehicular emissions, J. Geophys. Res., 10.1029/2001JD000720, 2002.

Pickering, K. E., Wang, Y., Tao, W.-K., Price, C., and Müller, J.F: Vertical distributions of lightning $\mathrm{NO}_{\mathrm{X}}$ for use in regional and global chemical transport models, J. Geophys. Res., 103, $31203-$ $31216,1998$.

Platt, U.: Differential optical absorption spectroscopy (DOAS), in Air Monitoring by Spectroscopic Techniques, M. W. Sigrist (Ed.), Chemical Analysis Series Vol. 127, John Wiley, New York, 1994.

Prados, A. I., Dickerson, R. R., Doddridge, B. G., Milne, P. A., Moody, J. L., and Merrill, J. T.: Transport of ozone and pollutants from North America to the North Atlantic Ocean during the 1996 Atmosphere/Ocean Chemistry Experiment (AEROCE) intensive, J. Geophys. Res. 104, 26 219-26 233, 1999.

Price, C., Penner, J., and Prather, M.: $\mathrm{NO}_{\mathrm{x}}$ from lightning - 1. Global distribution based on lightning physics, J. Geophys. Res. 102, 5929-5941, 1997.

Reeves, C. E., Claire, E., Penkett, S. A., et al.: Potential for photochemical ozone formation in the troposphere over the North Atlantic as derived from aircraft observations during ACSOE, J. Geophys. Res., 107, 4707, doi: 10.1029/2002JD002415, 2002.

Richter, A. and Burrows, J. P.: Tropospheric NO2 from GOME measurements, Adv. Space Res., 29, 1673-1683, 2002.

Roebber, P. J.: Statistical analysis and updated climatology of explosive cyclones, Mon. Wea. Rev., 112, 1577-1589, 1984.

Rozanov, V., Diebel, D., Spurr, R. J. D., and Burrows, J. P.: GOMETRAN: A radiative transfer model for the satellite project GOME - the plane parallel version, J. Geophys. Res., 102, 1668316696, 1997.

Sanders, F. and Gyakum, J. R.: Synoptic-dynamic climatology of the "bomb", Mon. Wea. Rev., 108, 1589-1606, 1980.

Sanders, F., Mullen, S. L., Baumhefner, D. P.: Ensemble simulations of explosive cyclogenesis at ranges of 2-5 days, Mon. Wea. Rev., 128, 2920-2934.

Seibert, P., Krüger, B., and Frank, A.: Parametrisation of convective mixing in a Lagrangian particle dispersion model, Proceedings of the 5th GLOREAM Workshop, Wengen, Switzerland, September 24-26, 2001.

Solomon, S., Schmeltekopf, A. L., and Sanders, R. W.: On the interpretation of zenith sky absorption measurements, J. Geophys. Res, 92, 8311-8319, 1987.

Spichtinger, N., Wenig, M., James, P., Wagner, T., Platt, U., and Stohl, A.: Satellite detection of a continental-scale plume of nitrogen oxides from boreal forest fires, Geophys. Res. Lett., 28, 4579-4582, 2001.

Stith, J., Dye, J., Ridley, B., Laroche, P., Defer, E., Baumann, K., Hübler, G., Zerr, R., and Venticinque, M.: NO signatures from lightning flashes, J. Geophys. Res., 104, 16 081-16 089, 1999.

Stohl, A.: A one-year Lagrangian "climatology" of airstreams in the northern hemisphere troposphere and lowermost stratosphere, J. Geophys. Res. 106, 7263-7279, 2001. 
Stohl, A., Eckhardt, S., Forster, C., James, P., and Spichtinger, N.: On the pathways and timescales of intercontinental air pollution transport, J. Geophys. Res., 107, 4684, doi: 10.1029/2001JD001396, 2002a.

Stohl, A., Trainer, M., Ryerson, T. B., Holloway, J. S., and Parrish, D. D.: Export of $\mathrm{NO}_{y}$ from the North American boundary layer during 1996 and 1997 North Atlantic Regional Experiments, J. Geophys. Res., 107, doi: 10.1029/2001JD000519, 2002b.

Stohl, A., Hittenberger, M., and Wotawa, G.: Validation of the Lagrangian particle dispersion model FLEXPART against large scale tracer experiment data, Atmos. Environ., 32, 4245-4264, 1998.

Stohl, A. and Trickl, T.: A textbook example of long-range transport: Simultaneous observation of ozone maxima of stratospheric and North American origin in the free troposphere over Europe, J. Geophys. Res., 104, 30 445-30 462, 1999.

Stohl, A. and Thomson, D. J.: A density correction for Lagrangian particle dispersion models, Boundary-Layer Meteorol., 90, 155167, 1999.

Stohl, A., Forster, C., Eckhardt, S., Spichtinger, N., Huntrieser, H., Heland, J., Schlager, H., Wilhelm, S., Arnold, F., and Cooper, O.: A backward modeling study of intercontinental pollution transport using aircraft measurements, J. Geophys. Res., in press, 2003
Ulbrich, U., Fink, A. H., Klawa, M., and Pinto, J. G.: Three extreme storms over Europe in December 1999, Weather, 56, 7080, 2001.

Velders, G. J. M., Granier, C., Portmann, R. W., Pfeilsticker, K., Wenig, M., Wagner, T., Platt, U., Richter, A., and Burrows, J. P.: Global tropospheric $\mathrm{NO}_{2}$ column distributions: Comparing 3-D model calculations with GOME measurements, J. Geophys. Res., 106, 12 643-12 660, 2001.

Wenig, M., Spichtinger, N., Stohl, A., Held, G., Beirle, S., Wagner, T., Jähne, B., and Platt, U.: Intercontinental transport of nitrogen oxide pollution plumes, Atmos. Chem. Phys. Discuss., 2, 21512165, 2002.

Wernli, H., Dirren, S., Liniger, M. A., and Zillig, F.: Dynamical aspects of the life cycle of the winter storm "Lothar" (24-26 December 1999), Q. J. R. Meteorol. Soc., 128, 405-429, 2002.

Wild, O., Law, K. S., McKenna, D. S., et al.: Photochemical trajectory modeling studies of the North Atlantic region during August 1993, J. Geophys. Res., 101, 29 269-29 288, 1996.

Zhu, Y. and Newell, R. E.: Atmospheric rivers and bombs, Geophys. Res. Lett., 21, 1999-2002, 1994.

Ziereis, H., Schlager, H., Schulte, P., van Velthoven, P. F. J., and Slemr, F.: Distributions of $\mathrm{NO}, \mathrm{NO}_{\mathrm{x}}$, and $\mathrm{NO}_{\mathrm{y}}$ in the upper troposphere and lower stratosphere between $28^{\circ}$ and $61^{\circ} \mathrm{N}$ during POLINAT 2, J. Geophys. Res., 105, 3653-3664, 2000. 